\title{
Algılanan Dışsal Prestijin Duygusal Emek Üzerindeki Etkisinde Ör- gütsel Özdeşleşmenin Aracılık Rolü: Konaklama İşletmelerinde Bir Araştırma $^{1}$
}

Algılanan Dışsal Prestijin Duygusal Emek Üzerindeki Etkisinde Örgütsel Özdeşleşmenin Aracılık Rolü: Konaklama İşletmelerinde Bir Araştırma

Öz

Bu çalışmanın amacı, konaklama işletmelerindeki işgörenlerin dışsal prestij algılarının sergiledikleri duygusal emek üzerindeki etkisinde örgütsel özdeşleşmenin aracılık rolünü ortaya koymaktır. Nevşehir ilinde bulunan turizm işletme belgeli dört ve beş yıldızlı konaklama işletmelerinde çalışan 506 işgören alan araştırmasına dâhil edilmiştir. Araştırmada kullanılan veriler, işgörenlere uygulanan anket yöntemi ile toplanmıştır. Verilerin analizi için merkezi eğilim ölçüleri, doğrulayıcı faktör analizi, korelasyon analizi ve yapısal eşitlik modellemesi gibi istatistiksel analiz yöntemleri kullanılmıştır. Elde edilen bulgulara göre, grup içi özdeşleşmenin duygusal çeliş̧i üzerinde tam aracılık, duygusal çaba üzerinde ise kısmi aracılık etkisi bulunmaktadır. Son olarak, ulaşılan bulguların örgütsel ortamlarda doğurabileceği sonuçlar değerlendirilerek, gerek araştırmacılara gerekse yöneticilere birtakım önerilerde bulunulmuştur.

Anahtar Kelimeler: Algılanan Dışsal Prestij, Örgütsel Özdeşleşme, Duygusal Emek, Aracılık Rolü, Yapısal Eşitlik Modeli, Konaklama İşletmeleri, Nevşehir
The Mediating Role of Organizational Identification on the Effects of Perceived External Prestige on Emotional Labor: A Research in Lodging Companies

Abstract

The purpose of the study is to investigate the mediating role of organizational identification on the effects of external prestige perceptions of employees in lodging companies on their emotional labor.506 employees who working in four and five-star lodging companies that certified tourism business in Nevsehir were included in the study. The data used in the research were collected by questionnaire method applied to employees. For the analysis of the data, statistical analysis methods such as central tendency measures, confirmatory factor analysis, correlation analysis and structural equation modeling were used. According to the results, the intra-group identification is full mediating effect on emotive dissonance and partial mediating effect on emotive effort. Finally, some suggestions were made to both the researchers and the managers by evaluating the results of the findings in organizational contexts.

Keywords: Perceived External Prestige, Organizational Identification, Emotional Labor, Mediating Role, Structural Equation Model, Lodging Companies, Nevsehir

\section{Giriş}

Hizmet sektörünün artan önemi ve ülke ekonomilerine sağladığı fayda, sektörün ülke ekonomisi içindeki ağırlığının bir gelişmişlik ölçütü olarak ele alınmasına yol açmıştır (Zengin ve Erdal, 2000: 43). Hizmet sektörünün önemli bir kısmını oluşturan ağırlama endüstrisi ise, tüm sektör içinde yatırım, istihdam ve katma değer büyüklüğü ile öne çıkmaktadır. Dünya'da ve Türkiye'de ağırlama endüstrisi, doğrudan ve dolaylı olarak toplumun büyük çoğunluğuna getiri sağlamakta, son yıllarda en hızlı gelişen ve değişen sektörler arasında yer almaktadır. Rekabetin

\footnotetext{
${ }^{1}$ Bu çalışma Gazi Üniversitesi, Sosyal Bilimler Enstitüsü, İşletme Anabilim Dalı'nda Prof. Dr. Enver Aydoğan danışmanlığında Gaye Deniz tarafından “Algılanan Dışsal Prestijin Duygusal Emek Üzerindeki Etkisinde Örgütsel Özdeşleşmenin Aracılık Rolü: Konaklama İşletmelerinde Bir Araştırma” ismiyle tamamlanarak 26.07.2017 tarihinde savunulan doktora tezinden türetilmiştir.

2 Öğr. Gör. Dr.,Nevşehir Hacı Bektaş Veli Üniversitesi, Turizm Fakültesi, Turizm İ̧̧letmeciliği Bölümü,gaye.yuksel@nevsehir.edu.tr, Yazar ORCID bilgisi: https://orcid.org/0000-0002-9980-8506.

3 Prof. Dr.,Ankara Hacı Bayram Veli Üniversitesi, iiBF, İşletme Bölümü,aydogan@gazi.edu.tr, Yazar ORCID bilgisi: https://orcid.org/0000-0001-7327-7148.
} 
son derece yoğun olduğu hizmet sektöründe yer alan işletmeler, sahip oldukları kaynakları etkili ve verimli bir biçimde kullanabildikleri sürece ayakta kalacak ve rekabet edebileceklerdir. Ağırlama endüstrisinin önemli bir bileşeni olan konaklama işletmelerinin emek yoğun bir sektör olması nedeniyle, sahip olduğu en değerli kaynak insan kaynaklarıdır. Konaklama işletmelerinin başarısı, büyük ölçüde işgücünün başarısına bağııdır. İnsanlar arası etkileşimin son derece fazla yaşandığı bu sektörde meydana gelen gelişmelerle birlikte, işgücünde aranan nitelikler de değişmeye başlamıştır. Hem memnuniyet bekleyen müşteri (sektörde genel kabul görmüş ismiyle "misafir") hem de verimlilik amacı taşıyan işletme açısından, işgörenlerin sahip oldukları fiziksel ve zihinsel yetkinliklerin yanında, duyguların yönetimi ve doğru bir şekilde gösterimi de arzu edilen bir nitelik haline gelmiştir.

"Duygusal emek" kavramı, yazına 1983 yılında Arlie Russell Hochschild'in yazdığı "Yönetilen Kalpler: İnsan Duygularının Ticarileşmesi" isimli kitapla girmiş ve "bir ücret karşııı̆ında satılan ve değişim değeri olan, genel olarak gözlemlenebilir yüz (mimik) ve beden gösterimi oluşturmak için duyguların yönetilmesi" olarak tanımlanmıştır (Hochschild, 1983: 7). Günümüzde özellikle hizmet sektöründe aranan en önemli kıstaslardan biri olan kalite vurgusuyla birlikte, duygusal emek davranış stratejilerine yönelik artan bir ilgi söz konusudur. Seçer ve Tınar'a (2004: 815) göre duygusal emek kullanmak hizmet kalitesini sağlamanın temel koşullarından biridir ve genellikle rol gereği olarak işgörenin, örgütün kendisinden sergilemesini istediği bazı duyguları göstermesi ya da istemediği bazı duyguları gizlemesine yönelik çabalarıdır. Sektörde yapılan işin bir parçası olarak görülen duygular, pozitif davranışa dönüştüğünde misafiri memnun ettiği gibi, hissedilmeyen duyguların sergilenmeye çalışılması da aynı zamanda işgörenlerin bu durumdan olumsuz bir şekilde etkilenmesine sebep olabilir. Duygusal emeğin olumsuz davranış stratejilerini ve sonuçlarını ortadan kaldıracak ya da en azından azaltacak öncüllerinin ele alınması gerekmektedir.

Bilgi çağında işletmeler açısından etkin hizmet sunmak kadar "algılanan dışsal prestij" de rekabetçi üstünlük sağlamada belirleyici faktörlerden birisidir. İ̧̧öreni her anlamda doyuma ulaşmış bir işletmenin verimliliği de yüksek olacaktır. Ne var ki, insan psikolojisi birçok örgütsel nedene bağlı olarak değişkenlik gösterir. Küreselleşmenin hızla yaşandığı bu dönemde, odak noktasına misafiri alan işletmelerin, doğrudan etkin bağlantı kurmak suretiyle, ilk seferde hizmet sunumunu iyi yaptıkları ve başarıya ulaştıkları görülmektedir. İşletme sektörde iyi şekilde lanse edildiğinde, işgören de bundan olumlu yönde etkilenecektir. "Dışarıdaki insanların örgüt hakkında ne düşündüğüne ilişkin bir işgörenin inancı" (Carmeli, 2005: 444) şeklinde ifade edilen algılanan dışsal prestij kavramının yazına son yıllarda dâhil olduğu görülmektedir. İşgörenler örgütlerini ne kadar çok prestijli olarak algılarsa, örgütle özdeşleşme düzeyi o ölçüde artacağından kendilerini kanıtlama potansiyelleri yüksek olacaktır (Fuller vd., 2006b: 702). Sürdürülebilir rekabetçi avantaj elde etmede müşteri hizmetlerinin artan rolüyle birlikte, örgütte yaşanan zorluklardan biri de misafirle etkileşim sırasında işgörenin kendisinden istenen duyguyu sergilemesi yönünde nasıl motive edileceğidir (Mishra vd., 2012: 204). “Örgütsel özdeşleşme” yüksek olduğunda, bireysel ve örgütsel amaçlar arasındaki bağlantıyı güçlendirir ve kişinin örgüt adına sergilediği hareketler, kişisel çıkarları ile uyumlu hale gelir. Sonuç olarak işgörenler, misafirle etkileşim sırasında kendisinden beklenen duyguları içselleştirebilir ve sergileyebilir. Bu açından bakıldığında işgörenlerin dışsal prestij algısının hem doğrudan hem de örgütsel özdeşleşme aracılığıyla duygusal emek davranışını etkileyebileceği düşünülmektedir.

Yazın taraması sonucunda görülen o ki, algılanan dışsal prestij ve örgütsel özdeşleşmenin duygusal emekle ilişkisini ayrı ayrı ve farklı sektörlerde inceleyen çalışmalar olmakla birlikte 
(Hochschild, 1983; Ashforth ve Humphrey, 1993; Schaubroeck ve Jones, 2000; Brotheridge ve Lee, 2003; Ünler Öz, 2007; Huynh vd., 2008; Mishra ve Bhatnagar, 2010; Mishra, 2011; Mishra vd., 2012; Burch vd., 2013; Mishra, 2013; Oktuğ, 2013; Zeng vd., 2014), konaklama sektöründe kavramların ayrı ayrı ele alınarak incelendiği araştırma sayısı sınırlıdır (Kim ve Han, 2009; Mishra, 2014; XiuLi ve YingKang 2016).Kavramların birlikte ele alınarak incelendiği çalışmaya hiç rastlanmamıştır. Dolayısıyla konunun öneminden hareketle bu çalışmada, konaklama işletmelerinde çalışan işgörenlerin dışsal prestij algıları ile sergiledikleri duygusal emek stratejileri arasında bir ilişkinin olduğu varsayılarak, örgütsel özdeşleşmenin bu ilişkide aracılık rolünün olup olmadığının araştırılması amaçlanmıştır.

Sözü edilen bilgiler ışığında yapılan bu araştırma neticesinde i) Türkiye'de önemli destinasyonlardan biri olan Nevşehir ilinde bulunan dört ve beş yıldızlı turizm işletme belgeli konaklama işletmelerinde çalışan işgörenlerin örgüte yönelik dışsal prestiji nasıl algıladığını belirlemek, ii) işgörenlerin sergilediği duygusal emek stratejilerini belirlemek ve dışsal prestij algılarıyla ilişkilendirmek, iii) bu değişkenler arasında bir ilişki varsa bu ilişkide örgütsel özdeşleşmenin aracılık etkisi olup olmadığını ortaya koymak, iv) yazında mevcut çalışmalar ile bu çalışmanın sonuçlarını karşılaştırmak v) böylece daha sonra bu değişkenler ile ilgili yapılacak olan çalışmalara yol göstermek ve vi) dışsal prestij algısı ve örgütsel özdeşleşme gibi pozitif oluşumları kullanarak duygusal emek sürecini örgüt lehine yönetmeye çalışan konaklama işletmeleri yöneticilerine öneriler sunmak hedeflenmektedir. Dolayısıyla bu değişkenlerin çalışmanın örneklemi olan konaklama işletmelerinde ilk kez ele alınması ve aralarındaki ilişkinin yapısal eşitlik modeli kullanılarak test edilmesi açısından yazındaki boşluğa olumlu bir katkı sağlayacağı düşünülmektedir.

\section{Kavramsal Çerçeve}

\subsection{Algılanan Dışsal Prestij}

Rekabetin yoğun olarak yaşandığı bir ortamda örgütlerin iyi bir prestije sahip olmaları, tüm paydaşlar açısından bir çekicilik unsuru oluşturur. Bu durum, gerek dış müşteriler gerekse iç müşteriler açısından da aynı öneme sahiptir. Algılanan dışsal prestij kavramı "çalıştığı örgüt dışında bulunan insanların, kurumu hakkında ne düşündüğüne dair işgörenin taşıdığı inanç" (Dutton ve Dukerich, 1991: 518) olarak tanımlanmaktadır. Örgütteki bireylerin örgütün dışında yer alan müşteri, rakip ve tedarikçi gibi paydaşların örgütü nasıl bulduklarına dair işgörenin inancı ve bu inanç doğrultusunda yaptığı değerlendirmelerden oluştuğundan (Carmeli, 2005: 444), aynı örgütün üyeleri arasında bile dışsal prestij algısı farklı olabilir. Algılanan dışsal prestij sonuçları, referans grupların düşünceleri, ağızdan ağıza iletişim ve işletmenin içsel ve dışsal iletişim çabaları gibi çeşitli bilgi kaynaklarından elde edilebilir (Smidts vd., 2001: 1052). Bu sayede işgörenler, çalıştıkları kurumu sosyal açıdan değerlendirebilir (Öcel, 2013: 39) ve örgütte çalışıyor olmalarının onlara sağladığı katkıyı daha objektif şekilde yordayabilirler.

Örgütlerin performansları ve verdikleri yaşam mücadeleleri büyük ölçüde paydaşlarına duydukları saygıyla birlikte kendi itibarlarına da bağlıdır.Bu anlamda algılanan dışsal prestijin örgütte, daha işgörenlerin işe alımından başlamak üzere işgören performansına varana dek pek çok faydasının bulunduğu da araştırmalarla desteklenmiştir (Yeşiltaş vd., 2011: 173).Örgütün sahip olduğu kimliğin prestije sahip olması, bireyin öz saygısına olumlu şekilde yansıyacak ve sosyal anlamda değerli bir örgüt algılaması işgörenin örgütüne karşı daha olumlu davranışlar geliştirmesini sağlayacaktır (Yeşiltaş vd., 2011: 174). Araştırmalar algılanan dışsal prestijin, işgörenlerin işteki etkinliği ve örgüte bağlııkları üzerinde olumlu etkilere sahip olduğunu (Herrbach vd., 2004), işgörenlere duygusal emek davranış stratejilerini düzenlemeleri gibi dolaylı yollardan da kazanç sağladığını (Fuller vd., 2006a; 2006c; Mishra vd., 2012) ve işgörenlerin dışsal prestij 
algıları arttıkça örgütle özdeşleşme düzeylerinin ve özsaygılarının da arttığını (Dutton vd., 1994; Iyer vd., 1997; Bergami ve Bagozzi, 2000; Carmeli ve Freund, 2002; Carmeli, 2005) işaret etmektedir.

\subsection{Duygusal Emek}

Müşteri odaklılık esasıyla çalışan hizmet sektöründe işgören-misafir etkileşiminin yoğun olarak yaşanmasının bir gereği olarak, çalışma süreçlerine duygusal emek de katılmakta ve işgörenden duygularını nihai amaçlara hizmet edecek şekilde yönetmesi ve sergilemesi beklenmektedir. Örgütsel davranış yazınında önemle ele alınmaya başlanan duygusal emeğin; “işi yapabilmek için gereken doğru duyguları hissetmeye çabalama ve bunu sergileme (Hochschild, 1990: 118)"; "uygun duyguların sergilenmesi eylemi (Ashforth ve Humphrey, 1993: 90)"; "kişiler arası etkileşim sürecinde kurumun istediği duyguları sergileyebilmek için sarf edilen çaba, planlama ve kontrol (Morris ve Feldman, 1996: 987-989)" gibi tanımlarına rastlanmaktadır. Duyguların ne zaman ve nasıl sergileneceğini dikte eden bazı standart ve kurallar vardır. Ekman (1973: 251) uygun duygusal ifade ile ilgili olarak bu tarz kuralları, "duygusal davranış kuralları" olarak adlandırmaktadır. Davranışların standartlaştırıldığı bu kurallar, yalnızca belirli bir durumda hangi duygunun uygun olduğunu değil, aynı zamanda nasıl açıkça ifade edilmesi gerektiğini de belirtir.Duygusal emek kullanımı, hizmet kalitesini sağlamanın temel koşullarından biri olarak görülmekte (Seçer ve Tınar, 2004: 815) ve duygusal emek davranış stratejilerine daha bir kontrolcü yaklaşılmaktadır.Dolayısıylaişletmeler, hizmet kalitesini üst düzeye taşımak suretiyle misafir tatminini arttırmak için işgörenlerden bazı davranış kurallarını sergilemelerini beklemektedirler (Özdemir vd., 2013: 302).

Yazında araştırmacıların duygusal emeği farklı boyutlarda ele aldıkları görülmektedir. Bu çaIışmada duygusal emek, Chu ve Murrmann'ın (2006) ağırlamada/konaklamada duygusal emek düzeyini ölçmek adına iki faktörlü modele dayanarak geliştirdikleri ölçekte yer alan boyutlar olan sürekliliğin bir ucunda yüzeysel rol yapmanın ve diğer ucunda gerçek duygunun olduğu durumu ölçen "duygusal çelişki" ve derinlemesine rol yapmayı ölçen "duygusal çaba" boyutlarıyla ele alınmıştır. Duygusal çabada işgören içsel duygularına odaklanarak, gerçek hislerini duygu gösterim kurallarıyla uyumlaştırmaya çalışmakta (Grandey, 2003: 96), sergilemek durumunda olduğu duyguyu deneyimleme çabası içine girmekte (Diefendorff ve Gosserand, 2003: 952) ve misafirlere hissettiği duyguyu aktarmaya çalışmaktadır. Duygusal çelişki ise, örgütlerde sergilenmesi gereken duygular ile gerçekten hissedilen duygular arasında yaşanan çatışma$\operatorname{dır(Middleton,~1989:~199).Duygusal~çabanın,~duygusal~çelişkiden~ayrılan~yönü,~bu~stratejide~}$ davranışlarla birlikte duyguların da davranış sergileme kurallarına uyumlaştırılmasıdır. Yalnızca duygu gösterim kurallarına uymak için sergilenen davranışlar gerçekten yaşanmadığında, mecburiyetten sergilenen bu davranışlar pek çok olumsuz iş çıktısına neden olabilecektir.

\section{3. Örgütsel Özdeşleşme}

Örgütsel özdeşleşme; işgören ve örgüt arasındaki ilişkide yaşanan birçok tutum ve davranışı açıklayan bir kavramdır (Edwards, 2005: 207). Bu nedenle işgörenlerinin hem zihninde hem de gönlünde yer edinmeye çalışan örgütler aradaki bağı güçlendirmeye çalışırlar (Albert vd.,2000: 13). Özdeşleşmeyi ilk olarak Freud "psikanalizde özdeşim, başka bir insanla kurulan duygusal bağın ilk dışavurumudur" şeklinde tanımlamıştır (Akyüz ve Yılmaz, 2015: 138). Genel olarak örgütsel özdeşleşme, "örgütle bir olma algısı ve örgütün başarı ve başarısızlıklarını kendi başarı ve başarısızlıkları gibi yaşamak (Mael ve Ashforth, 1992: 123) ve psikolojik olarak örgütü kendinin bir parçası olarak hissetmek (Turunç ve Çelik, 2010: 164)" olarak tanımlanmaktadır. İşcan'a 
(2006: 162) göre örgütsel özdeşleşmeyle ilgili tanımların ortak yönü, hepsinin örgüt üyesinin örgüt üyeliğini benliğiyle ya bilişsel olarak ya duygusal olarak veya her iki şekilde birden ilişkilendirmesinden söz etmesidir. Örgütü ile yoğun bir etkileşimde bulunduğunda, örgütünün kişisel amaçlarıyla örtüştüğünü düşündüğünde, çalıştığı örgütün prestijini yüksek olarak algıladığında, örgütteki işleri ve bireyleri yüksek statülü bulduğunda bireyin örgütüyle özdeşleşme eğilimi artacaktır (Sezgin Nartgün ve Kalay, 2014: 1363-1364). Kişilerin örgütleriyle özdeşleşmeleri arttıkça, örgütsel perspektiften bakarak düşünme ve davranma düzeyleri de artar (Dutton vd., 1994: 240). Bu nedenle örgütsel özdeşleşmeyi arttırmak adına, işletme yöneticilerinin uygun araçları seçmeleri ve işgörenlerinin ihtiyaçlarını, onları motive eden faktörleri bilmeleri gerekmektedir (Smidts vd., 2001: 1053).

Yazındaki çalışmalarda özdeşleşmenin çoğunlukla tek boyutlu olarak ele alındığı görülmektedir. Oysaki boyut ortalamalarının farklı seviyelerde çıktığı görgül araştırmalarda, gerek örgütle özdeşleşmenin gerekse grup içi özdeşleşmenin birbiriyle ilişkili ancak farklı yapılar olduğu ortaya konmuştur (Knippenberg ve Van Schie, 2000;Reade, 2001; Bartels vd., 2007). Bu nedenle, bu çalışmada örgütsel özdeşleşme, örgütle özdeşleşme ve grup içi özdeşleşme boyutlarıyla ele alınmıştır. Örgütün bütününe kıyasla işgörenlerin, çalışma gruplarıyla paylaştıkları yaşanmışlık ve ortak geçmiş daha kuvvetlidir. Bu nedenle grup içi özdeşleşme, tüm örgütle özdeşleşmeden daha güçlü bir yapıya sahiptir (Knippenberg ve Van Schie, 2000: 139).

\section{Araştırma Modeli ve Hipotezler}

\subsection{Araştırma Modeli}

Konaklama işletmelerinde çalışan işgörenlerin örgüte dair dışsal prestij algıları ile sergiledikleri duygusal emek stratejileri arasındaki ilişki ve bu ilişkide örgütsel özdeşleşmenin aracılık rolünün incelendiği bu çalışmada, araştırma modeli Baron ve Kenny (1986) tarafından önerilen modele göre oluşturulmuştur (Şekil 1).

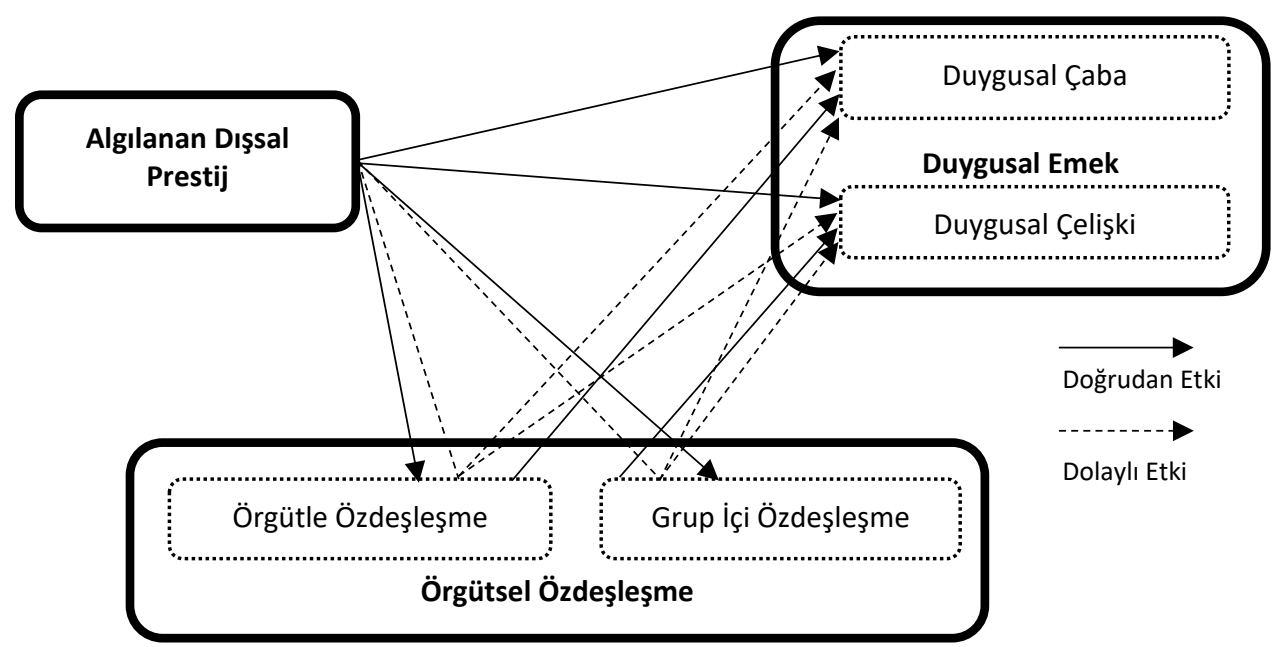

Şekil 1: Kavramsal Araştırma Modeli 


\subsection{Hipotezler}

\subsubsection{Algılanan Dışsal Prestij ve Duygusal Emek}

Dışsal prestij algısı, işgörenlerin kendilerini geliştirme gereksinimlerini karşıladığı için, işgörenler işlerini bir ödül gibi algılamaktadır. Yapılan iş, işgöreni ne kadar çok ödüllendiriyorsa, işgören o kadar gerçekçi duygular sergilemektedir (Hochschild, 2003: 155). Davranış sergileme kurallarına uymanın meşru olarak kendilerinden beklendiğini düşünen ve davranışlarının örgütleri için faydalı olduğuna inanan işgörenler, istenen duyguları içselleştirmek ve sergilemek için misafirle etkileşimleri sırasında çaba sarf ederek kendilerini samimi davranmaya iteceklerdir. Aksine işgörenler, örgütlerinin algılanan dışsal prestiji çekici olmadığında, samimiyetsizlik numarası yapmalarına yol açan davranışlarının, işin bir parçası olmaması gerektiğine inanırlar (Zerbe, 2002: 191). Dolayısıyla algılanan dışsal prestijin düşük olarak algılandığı durumlarda işgörenler, duygusal çelişki yoluyla duygusal emek sergileyeceklerdir. Nitekim, yapılan araştırmalar da algılanan dışsal prestijin, duygusal çabayla pozitif, duygusal çelişkiyle negatif olarak ilişkili olduğunu ortaya koymaktadır (Mishra,2011; Mishra vd., 2012; Oktuğ, 2013). Algılanan dışsal prestij ve duygusal emek arasındaki ilişkiye yönelik aşağıdaki hipotezler geliştirilmiştir:

Hipotez 1: Algılanan dışsal prestij, duygusal emeğin duygusal çaba boyutu üzerinde aynı yönde ve anlamlı bir etkiye sahiptir.

Hipotez 2: Algılanan dışsal prestij, duygusal emeğin duygusal çelişki boyutu üzerinde ters yönde ve anlamlı bir etkiye sahiptir.

\subsubsection{Algılanan Dışsal Prestij ve Örgütsel Özdeşleşme}

Örgüt ne kadar prestijli olarak görülüyorsa, örgütle olan bağlantısı özsaygısını arttırdığı için birey de o derece örgütle özdeşleşecektir (Smidts vd., 2001: 1052). Yani bireyler örgütlerinin, örgüt dışında bulunan önemli paydaşlar tarafından büyük beğeniyle karşılandığına inandıklarında, örgütleriyle daha güçlü bir özdeşleşme eğilimi sergilemektedirler (March ve Simon, 1958; Wan-Huggins vd., 1998; Podnar, 2011). Yazındaki çalışmalarda daha çok, örgütsel düzeyde algılanan dışsal prestijin, üyelerin örgütün bütünüyle özdeşleşmelerine ve işgörenlerin tutum ve davranışları üzerindeki etkisine odaklanılmıştır (Dutton ve Dukerich, 1991; Bhattacharya vd., 1995; Bergami ve Bagozzi, 2000; Carmeli ve Freund, 2002; Herr-bach vd., 2004; Karabey ve İşcan, 2007; Bartels vd., 2009; Tak ve Çiftçioğlu, 2009; Kim vd., 2010; Epitropaki, 2013). Ancak bazı araştırmacılar, prestij algısını hem örgüt hem de grup düzeyinde ele almak gerektiğinin önemine vurgu yapmışlardır. Bireyler kendi prestijlerini geliştiren gruplarla özdeşleşme eğilimindedirler ve grup ne kadar prestijli olursa, bireyin de örgütün amaçlarına hizmet etme olasılı̆̆ı o kadar yüksek olmaktadır (Lee, 1971; Ashforth ve Mael, 1989; Mael ve Ashforth, 1992; Bamber ve lyer, 2002; Lipponen vd., 2005; Jetten vd., 2005; Carmeli ve Shteigman, 2010; Carmeli vd., 2011; Liu vd., 2014). Algılanan dışsal prestij ve örgütsel özdeşleşme arasındaki ilişkiye yönelik aşağıdaki hipotezler geliştirilmiştir:

Hipotez 3: Algılanan dışsal prestij, örgütsel özdeşleşmenin örgütle özdeşleşme boyutu üzerinde aynı yönde ve anlamlı bir etkiye sahiptir.

Hipotez 4: Algılanan dışsal prestij, örgütsel özdeşleşmenin grup içi özdeşleşme boyutu üzerinde aynı yönde ve anlamlı bir etkiye sahiptir. 


\subsection{3. Örgütsel Özdeşleşme ve Duygusal Emek}

Örgütüyle güçlü bir şekilde özdeşleşen işgörenlerin örgütsel açıdan düşünme olasılıkları yükselir (Bullis ve Tompkins, 1989: 287) ve örgütün çıkarları doğrultusunda hareket ederler (Mael ve Ashforth, 1992: 116). Bireyin işine ya da örgüte yönelik özdeşleşmesi, işyerinde duygusal emeği nasıl sergilediğini etkiler (Schaubroeck ve Jones 2000: 165). Diğer bir deyişle, işgören örgütüyle daha çok özdeşleştikçe, örgütsel açıdan beklenen duyguları daha fazla içselleştirecek ve sonuç olarak işinde daha az duygusal çelişki sergileyecektir (Ashforth ve Tomiuk, 2000; Côté, 2005; Mishra ve Bhatnagar, 2010; Mishra, 2014). Kişi, örgüt tarafından belirlenen davranış kurallarıyla ne kadar özdeşleşirse, daha gerçekçi davranışlar gösterir. İşteki rolleriyle yüksek düzeyde özdeşleşen bireyler ise duygusal çelişki davranışından ziyade duygusal çaba davranışı sergileyeceklerdir (Brotheridge ve Lee, 2003; Ünler Öz, 2007; Burch vd., 2013). Örgütsel özdeşleşme ve duygusal emek arasındaki ilişkiye yönelik aşağıdaki hipotezler geliştirilmiştir:

Hipotez 5: Örgütsel özdeşleşmenin örgütle özdeşleşme boyutu, duygusal emeğin duygusal çaba boyutu üzerinde aynı yönde ve anlamlı bir etkiye sahiptir.

Hipotez 6: Örgütsel özdeşleşmenin örgütle özdeşleşme boyutu, duygusal emeğin duygusal çelişki boyutu üzerinde ters yönde ve anlamlı bir etkiye sahiptir.

Hipotez 7: Örgütsel özdeşleşmenin grup içi özdeşleşme boyutu, duygusal emeğin duygusal çaba boyutu üzerinde aynı yönde ve anlamlı bir etkiye sahiptir.

Hipotez 8: Örgütsel özdeşleşmenin grup içi özdeşleşme boyutu, duygusal emeğin duygusal çelişki boyutu üzerinde ters yönde ve anlamlı bir etkiye sahiptir.

\subsection{4. Örgütsel Özdeşleşmenin Aracılık Rolü}

İşgörenlerin örgütün dışsal prestijine yönelik olumlu algıları, örgütleriyle özdeşleşmelerine neden olur ve bu da işgörenleri misafirle etkileşimleri sırasında duygusal çaba davranışı sergilemeye yönlendirir. Dışsal prestijin olumsuz olarak algılanması bireylerin örgütle özdeşleşmelerini azaltacaktır. İşgörenler kendilerini örgütleriyle özdeşleştirmediklerinde, gruba üye olmanın değerinin düşük olduğunu düşünürler, grup normlarına çok az uyum gösterme eğiliminde olurlar (Homans, 1961: 354) ve örgüt yararına hareket etmezler (Bhattacharya ve Elsbach, 2002: 27). Dolayısıyla algılanan dışsal prestijin düşük olarak algılandığı durumlarda işgörenler duygusal çelişki yoluyla duygusal emek sergileyeceklerdir (Mishra, 2011: 123). Mishra ve diğerleri (2012: 209) Hindistan'da ilaç sektöründe yaptıkları çalışmada, algılanan dışsal prestijin, örgütsel özdeşleşme ve duygusal çaba davranışıyla pozitif, duygusal çelişki davranışıyla negatif olarak ilişkili olduğunu ortaya koymuşlardır. Ayrıca, örgütsel özdeşleşmenin, hem algılanan dışsal prestij ile duygusal çaba davranışı arasında, hem de algılanan dışsal prestij ile duygusal çelişki davranışı arasında aracılık rolüne sahip olduğunu belirtmişlerdir. Bu çalışmada ise Nevşehir ilinde bulunan dört ve beş yıldızlı otellerde konunun araştırılması esas alınmıştır. Her iki çalışmada da aynı yöntem kullanılmış olmakla birlikte, hizmet sektörünün diğer bir kolu olan ağırlama hizmetlerinde de benzer sonuçların alınıp alınamayacağı anlaşılmaya çalışılmıştır. Buna göre, algılanan dışsal prestij ve duygusal emek arasındaki ilişkide örgütsel özdeşleşmenin aracılık rolünü belirlemeye yönelik aşağıdaki hipotezler geliştirilmiştir:

Hipotez 9: Örgütsel özdeşleşmenin örgütle özdeşleşme boyutu, algılanan dışsal prestij ile duygusal emeğin duygusal çaba boyutu arasındaki ilişkide aracı rolü oynayacaktır.

Hipotez 10: Örgütsel özdeşleşmenin örgütle özdeşleşme boyutu, algılanan dışsal prestij ile duygusal emeğin duygusal çelişki boyutu arasındaki ilişkide aracı rolü oynayacaktır. 
Hipotez 11: Örgütsel özdeşleşmenin grup içi özdeşleşme boyutu, algılanan dışsal prestij ile duygusal emeğin duygusal çaba boyutu arasındaki ilişkide aracı rolü oynayacaktır.

Hipotez 12: Örgütsel özdeşleşmenin grup içi özdeşleşme boyutu, algılanan dışsal prestij ile duygusal emeğin duygusal çelişki boyutu arasındaki ilişkide aracı rolü oynayacaktır.

\section{Araştırmanın Yöntemi}

İlgili yazın incelendiğinde, gerek algılanan dışsal prestijin gerekse örgütsel özdeşleşmenin duygusal emek üzerindeki etkisini farklı sektörlerde inceleyen araştırmalar görülmekle birlikte (Ashforth ve Humphrey 1993; Brotheridge ve Lee, 2003; Burch vd., 2013; Hochschild, 1983; Huynh vd., 2008; Mishra ve Bhatnagar, 2010; Mishra, 2011; Mishra vd., 2012; Mishra, 2013; Oktuğ, 2013; Schaubroeck ve Jones 2000; Ünler Öz, 2007; Zeng vd., 2014), konaklama sektöründe kavramların ayrı ayrı ele alınarak incelendiği araştırma sayısının sınırlı olduğu dikkati çekmektedir (Kim ve Han, 2009; Mishra, 2014; XiuLi ve YingKang, 2016). Ayrıca konaklama sektöründe kavramların birlikte ele alınarak incelendiği çalışmaya hiç rastlanmamıştır. Bu düşünceden hareketle, söz konusu kavramlar ile duygusal emek davranış stratejileri arasındaki ilişkiler çok boyutlu olarak incelenerek, yazındaki boşluğa olumlu bir katkı sağlayacağı düşünülmektedir.

T.C. Kültür ve Turizm Bakanlığı, Yatırım ve İşletmeler Genel Müdürlüğü’nün resmi istatistik verilerine göre (2015) Türkiye'de "Turizm İşletme Belgeli" tesis sayısı 3309, araştırmanın yapıldığı Nevşehir ilinde ise 65'tir. Tüm yıl boyunca turizm sezonunun devam ettiği Kapadokya bölgesinde bulunan turizm işletme belgeli konaklama işletmeleri, aynı zamanda bölgenin sürdürülebilir turizm potansiyelini arttıran önemli arz kaynaklarından birini oluşturur. Özellikle sundukları hizmet çeşitliliği, hizmetin kalitesi ve standardizasyonu bakımından dört ve beş yıldızlı otel işletmeleri, Kapadokya bölgesinde de gelen turistlerin konaklamayı tercih ettiği işletmeler olmaktadır. Çalışmanın evreni, Nevşehir ilinde bulunan, Kültür ve Turizm Bakanlığı'ndan “Turizm İ̧̧letme Belgeli Tesis" statüsüne sahip dört ve beş yıldızlı otellerde çalışan işgörenler olarak belirlenmiştir. Nevşehir il Kültür ve Turizm Müdürlüğü’nün 2017 yılı verilerine göre, Nevşehir ilinde 2733 yatak kapasiteli beş adet beş yıldızlı ve 3612 yatak kapasiteli 14 adet dört yıldızlı otel işletmesi bulunmaktadır. Söz konusu otellerin insan kaynakları birimlerinden alınan bilgiye göre 2017 yılının Ocak-Şubat aylarında toplam personel sayısının yaklaşık 675 kişi olduğu tespit edilmiştir. Araştırmada tesadüfî olmayan örnekleme yöntemlerinden biri olan amaçlı (yargısal/kasti/iradi) örnekleme yöntemi kullanılmıştır. Bu örneklemenin esası ana kütle içerisinden, gözle tahmin ederek, bilgi edinmek istenen özelliği temsil edebilecek birimleri ayırmaktır (Yazıcıoğlu ve Erdoğan, 2011: 82). Otel işletmelerinin yatak kapasitelerine göre hesaplama yapılmış ve evreni temsil edebilecek örneklem hacmi, \%95 güven aralı̆ı̆nda \%5 hata payı göz önünde bulundurularak 340 işgören olarak belirlenmiştir. Veriler anket formu aracılığıyla toplanmıştır. Yazar tarafından anketi uygulamayı kabul eden 12 adet dört ve beş yıldızlı otel işletmesine 02 Ocak-24 Mart 2017 tarihleri arasında toplam 600 anket dağıtıımış ve 531'i geri dönmüştür. \%89 geri dönüş oranı bilimsel açıdan kabul edilebilir (Büyüköztürk, 2005). Ankette fazla sayıda soruyu yanıtlamayan ya da işaretlemeleri alt veya üst değerlerde toplanan veriler analizden çıkarılmış, analizlere 506 kişilik bir örneklem üzerinden devam edilmiştir.

\subsection{Prosedür}

Konaklama işletmelerinde çalışan işgörenlerin eğilimlerini ölçmek amacıyla kullanılan ölçekler anket formu aracılığıyla işgörenlere sorulmuştur. Cevaplar 5'li likert ölçeğiyle alınmıştır 
(1=Kesinlikle Katılmıyorum, 2=Katılmıyorum, 3=Ne Katılıyorum Ne Katılmıyorum, 4=Katılıyorum, $5=$ =Kesinlikle Katılıyorum). Çalışmada kullanılan her üç ölçek de Türkçe yazında güvenilirliği ve geçerliliği test edilmiş ölçeklerdir.

- Algılanan Dışsal Prestij Ölçeği: İşgörenlerin dışsal prestij algılarını ölçmek için Mael ve Ashforth'un (1992, $\alpha=0,77)$ geliştirdiği ölçekten faydalanılmıştır. Ölçek sekiz maddelik ifadeden oluşmaktadır. Ölçeğin Türkçe formunun ölçme gücünün yeterli olduğu (Güleryüz 2010, ( $\alpha=0,80)$; Gürbüz 2010, ( $\alpha=0,83)$; Tak ve Çiftçioğlu 2009, $(\alpha=0,79)$ ) ve konaklama işletmelerinde de uygulandığı (Tuna vd. 2016, $(\alpha=0,74)$ ) ortaya konmuştur. Bu çalışmada ölçeğin güvenilirlik katsayısı (Cronbach Alfa) 0,89 olarak hesaplanmıştır.

- Örgütsel Özdeşleşme Ölçeği: İşgörenlerin örgütsel özdeşleşme seviyelerini ölçmek amacıyla Mael ve Ashforth $(1992, \alpha=0,87)$ tarafından geliştirilen ve Tokgöz'ün $(2012, \alpha=0,92)$ çalışmasında örgütle özdeşleşme ve grup içi özdeşleşme boyutlarıyla geçerliliği sınanan örgütsel özdeşleşme ölçeğinden faydalanılmıştır. Boyutları değerlendirmek amacıyla ölçeği oluşturan sorular her iki boyuta da uyarlanarak sorulmuştur. Ölçek 12 maddelik ifadeden oluşmaktadır. Bu çalışmada ölçeğin güvenilirlik katsayısı 0,90 (örgütle özdeşleşme $\alpha=0,85$, grup içi özdeşleşme $\alpha=0,83$ ) olarak hesaplanmıştır.

- Duygusal Emek Ölçeği: İşgörenlerin sergiledikleri duygusal emeği ölçmek için, Chu ve Murrmann (2006, duygusal çaba $\alpha=0,77$, duygusal çelişki $\alpha=0,89$ ) tarafından geliştirilen, Pala (2008, $\alpha=0,85, \alpha=0,71$ ) tarafından Türkçeye uyarlaması yapılan ve Avcı ve Boylu (2010, $\alpha=0,74 \alpha=0,86$ ) tarafından Türk turizm çalışanları için geçerlemesi yapılan (ağırlama/konaklama) duygusal emek ölçeği kullanılmıştır. Ölçek 13 maddelik ifadeden oluşmaktadır. Bu çalışmada ölçeğin güvenilirlik katsayısı 0,76 (duygusal çaba $\alpha=0,86$, duygusal çelişki $\alpha=0,88$ ) olarak hesaplanmıştır.

\subsection{Katılımcı Profili}

Araştırmaya katılan işgörenlerin \% 48,2'si 26-35 yaş aralığında, \% 65,8'i erkek, \% 63'ü evli, $\% 45,7$ 'si lise ve dengi okul mezunu, \% 37,7'si 6-10 yıl arasında tecrübeye sahiptir. Katılımcıların \%35,6'sı turizm eğitimi almıştır ve çoğunluğu önbüro, kat hizmetleri ve yiyecek-içecek departmanı işgörenleridir. Turizm sektöründe ve otelde çalışma sürelerinin kısa olmasının sektörün sirkülasyon özelliğinin fazla olmasından kaynaklandığı söylenebilir. Anketi yanıtlayanların çoğunlukla departman elemanı olması ve genellikle sekiz saatlik çalışma sürelerine sahip olmaları da öne çıkan bulgular arasındadır.

\subsection{Veri Analizi}

Verilerin analizinde SPSS 24.0 ve AMOS 24.0 istatistik programlarından yararlanılarak yapısal eşitlik modeli sınanmıştır. Öncelikle verilerin analize uygunluğu incelenerek, veri setinin normal dağılım sergilediği ve parametrik testlerin kullanımı için gerekli koşulları taşıdığı ortaya konmuştur. Sonrasında araştırmada kullanılan ölçeklerin güvenilirlik ve geçerlilikleri test edilmiş ve katılımcıların profillerini yansıtan frekans analizleri yapılmıştır. Değişkenler arasındaki nedensel ilişkileri ve etkileri ortaya koymak amacıyla yapısal regresyon modelleri oluşturulmuş ve yol analizi uygulanmıştır. Önerilen modelin uygunluğunu değerlendirmek için ki-kare $\left(\mathrm{X}^{2}\right)$, serbestlik derecesi (df) ve ki-kare/df oranlarına, iyilik uyum indeksine (GFI), karşılaştırmalı uyum indeksine (CFI) ve yaklaşık hataların ortalama kareköküne (RMSEA) bakıımıştır. 


\subsection{Araştırmanın Geçerlilik ve Güvenilirliği (Doğrulama)}

Doğrulayıcı faktör analizi için örneklem büyüklüğünün yeterliliğini kontrol etmek amacıyla Kaiser-Meyer-Olkin (KMO) testi kullanılmıştır. KMO değerinin 0,90 olması örneklem büyüklüğünün yeterli olduğunu göstermiştir. Ölçekleri test etmek amacıyla AMOS 24.0 istatistik programı kullanılarak algılanan dışsal prestij ölçeğine tek faktörlü DFA, örgütsel özdeşleşme ve duygusal emek ölçeklerine birinci düzey DFAuygulanmıştır. Doğrulayıcı faktör analizi sonucunda model uyum değerlerinin kabul edilebilir düzeyde olmadıkları görülmüştür. Bu nedenle, kurama göre (Hair vd., 1998) kurulabilen ve düzeltme değeri olarak modele en yüksek katkıyı sağlayan modifikasyonlar yapılmıştır. Modifikasyon sonrası algılanan dışsal prestij $\left(x^{2}=10,659, \mathrm{df}=3, p=\right.$ , $000 ; x^{2} / d f=3,553, G F I=0,99, C F I=0,99$, RMSEA =0,071), örgütsel özdeşleşme $\left(x^{2}=88,126, d f\right.$ $\left.=30, p=, 000 ; x^{2} / d f=2,938, \mathrm{GFI}=0,97, \mathrm{CFI}=0,98, \mathrm{RMSEA}=0,062\right)$ ve duygusal emek $\left(\mathrm{x}^{2}=\right.$ $170,686, \mathrm{df}=41, \mathrm{p}=, 000 ; \mathrm{x}^{2} / \mathrm{df}=4,163, \mathrm{GFI}=0,94, \mathrm{CFI}=0,95, \mathrm{RMSEA}=0,079$ ) ölçeklerine yönelik uyum iyiliği değerlerinin kabul edilebilirsınırlar içinde olduğu görülmüştür. Dolayısıyla algılanan dışsal prestij ölçeğinin tek faktörlü yapısı, örgütsel özdeşleşme ve duygusal emek ölçeklerinin birinci düzey iki faktörlü yapısı doğrulanmıştır. Yapılan analiz sonucunda ifadelerin faktör yükleri ile ölçeklerin güvenilirliğine ilişkin Cronbach Alfa katsayıları Tablo 1'de sunulmuştur.

Tablo 1:Ölçeklerin Faktör Yükleri ve Cronbach Alfa Katsayıları

\begin{tabular}{|c|c|c|c|}
\hline ifadeler & Kod & $\begin{array}{l}\text { Faktör } \\
\text { Yükü }\end{array}$ & $\begin{array}{l}\text { Cronbach } \\
\text { Alfa }\end{array}$ \\
\hline Algılanan Dışsal Prestij & ADP & & \\
\hline Çevremdeki insanların, çalıştığım otel hakkındaki düşünceleri olumludur. & ADP1 & 0,92 & \multirow{4}{*}{0,89} \\
\hline Bu otelde çalışıyor olmanın bir saygınlığı vardır. & ADP2 & 0,94 & \\
\hline \multirow{2}{*}{$\begin{array}{l}\text { Çalıştığım otel, alanının en iyilerinden biri olarak kabul edilir. } \\
\text { Çevremdeki herkes, bir yakınının bu otelde çalışmasından gurur duyacak- } \\
\text { tır. }\end{array}$} & ADP3 & 0,81 & \\
\hline & ADP5 & 0,57 & \\
\hline Örgütsel Özdeşleşme & öö & \multicolumn{2}{|r|}{0,90} \\
\hline \multicolumn{4}{|l|}{ Örgütle Özdeşleşme } \\
\hline Herhangi bir kişi çalıştığım oteli eleştirdiğinde üzüntü duyarım. & ÖÖ1 & 0,59 & \multirow{5}{*}{0,85} \\
\hline Başkalarının çalıştığım otel hakkındaki düşünceleri benim için önemlidir. & ÖÖ2 & 0,67 & \\
\hline Çalıştığım otelden bahsederken, “onlar” değil, "biz" diye konuşurum. & ÖÖ3 & 0,81 & \\
\hline Çalıştığım otelin başarısını kendi başarım gibi görürüm. & ÖÖ4 & 0,76 & \\
\hline $\begin{array}{l}\text { Herhangi bir kişi çalıştığım oteli övdüğünde, bunu kendime bir övgü gibi } \\
\text { hissederim. }\end{array}$ & ÖÖ5 & 0,76 & \\
\hline \multicolumn{4}{|l|}{ Grup İçi Özdeşleşme } \\
\hline Herhangi bir kişi çalıştığım departmanı eleştirdiğinde üzüntü duyarım. & GiÖ1 & 0,60 & \multirow{5}{*}{0,83} \\
\hline $\begin{array}{l}\text { Başkalarının çalıştığım departman hakkındaki düşünceleri benim için } \\
\text { önemlidir. }\end{array}$ & GiÖ2 & 0,65 & \\
\hline $\begin{array}{l}\text { Çalıştığım departmandan bahsederken, "onlar" değil, "biz" diye konuşu- } \\
\text { rum. }\end{array}$ & GiÖ3 & 0,78 & \\
\hline Çalıştığım departmanın başarısını kendi başarım gibi görürüm. & GiÖ4 & 0,70 & \\
\hline $\begin{array}{l}\text { Herhangi bir kişi çalıştığım departmanı övdüğünde, bunu kendime bir } \\
\text { övgü gibi hissederim. }\end{array}$ & GiÖ5 & 0,64 & \\
\hline Duygusal Emek & DE & & 0,76 \\
\hline \multicolumn{4}{|l|}{ Duygusal Çaba } \\
\hline $\begin{array}{l}\text { Misafirlere karşı sergilemem gereken hislere bürünmek için gerçek hisle- } \\
\text { rimi değiştirmeye çalışırım. }\end{array}$ & DÇA1 & 0,80 & \multirow{2}{*}{0,86} \\
\hline $\begin{array}{l}\text { Misafirlerle ilgilenirken işletmenin sergilemeye çalıştığı imaja uygun duy- } \\
\text { guları hissetmeye çalışırım. }\end{array}$ & DÇA2 & 0,78 & \\
\hline
\end{tabular}




\begin{tabular}{|c|c|c|c|}
\hline $\begin{array}{l}\text { Misafirlere yardım ederken gerçekte hissettiğim duygulardan kurtulmak } \\
\text { için kendimi zorlarım. }\end{array}$ & DÇA3 & 0,68 & \\
\hline $\begin{array}{l}\text { Misafirlere karşı sergilemem gereken duyguları sergileyebilmek için çaba } \\
\text { harcarım. }\end{array}$ & DÇA4 & 0,83 & \\
\hline $\begin{array}{l}\text { Gerçekte hissetmediğim duyguları yansıtırken davranışıma daha fazla } \\
\text { dikkat etmek zorunda kalırım. }\end{array}$ & DÇA5 & 0,69 & \\
\hline \multicolumn{4}{|l|}{ Duygusal Çelişki } \\
\hline Misafirlerle ilgilenirken göstermelik hisler sergilerim. & DÇE1 & 0,62 & \multirow{6}{*}{0,88} \\
\hline Misafirlerle ilgilenirken yansıttığım duygular yapmacıktır. & DÇE2 & 0,74 & \\
\hline Misafirlere karşı gerçekte hissettiklerimden farklı davranırım. & DÇE4 & 0,77 & \\
\hline Misafirlerle gereken şekilde ilgilenmek için rol yaparım. & DÇE5 & 0,79 & \\
\hline Misafirlerle ilgilenirken robot gibiyimdir. & DÇE6 & 0,79 & \\
\hline Misafirlerle ilgilenirken gerçek hislerimi saklamak zorunda kalırım. & DÇE7 & 0,62 & \\
\hline
\end{tabular}

Elde edilen sonuçlar, algılanan dışsal prestij, örgütsel özdeşleşme ve duygusal emek ölçeklerinin geçerli ve güvenilir ölçekler olduğunu ve sonraki araştırmalar için de kullanılabileceğini göstermektedir.

\subsection{Araştırmanın Bulguları}

Çalışmanın kuramsal çerçevesi doğrultusunda geliştirilen araştırma hipotezlerinin sınanabilmesi için korelasyon analizinden ve yapısal regresyon modellerinden yararlanılmıştır.

\subsubsection{Algılanan Dışsal Prestij ve Duygusal Emek Arasındaki ilişki}

Algılanan dışsal prestijin duygusal emek ile olan ilişkisini ortaya çıkarmak amacıyla Pearson korelasyonu hesaplanarak, yapısal regresyon modeli aracılığıyla algılanan dışsal prestijin duygusal emek üzerindeki etkisi analiz edilmiştir. Korelasyon bulgularına göre; algılanan dışsal prestij ile duygusal emeğin duygusal çaba boyutu $(r=0,321 ; p<0,01)$ ile arasında istatistiksel açıdan anlamlı, pozitif ve orta dereceli bir ilişki ve duygusal çelişki boyutu $(r=-0,334 ; p<0,01)$ ile arasında istatistiksel açıdan anlamlı, negatif ve orta dereceli bir ilişki bulunmaktadır. Algılanan dışsal prestijin duygusal emek üzerindeki etkisini ölçmek üzere oluşturulan yapısal regresyon modelinin uyum değerlerinin $\left(\mathrm{x}^{2}=249,254, \mathrm{df}=85, \mathrm{p}=, 000 ; \mathrm{x}^{2} / \mathrm{df}=2,932, \mathrm{GFI}=0,94, \mathrm{CFI}=\right.$ $0,96, \mathrm{RMSEA}=0,062$ ) kabul edilebilir sınırlar içinde olması, modelin yapısal olarak uygun olduğunu göstermektedir.Modele göre, algılanan dışsal prestij, duygusal emeğin boyutlarından duygusal çabayı $(\beta=0,51 ; p<0,01)$ ve duygusal çelişkiyi $(\beta=-0,27 ; p<0,01)$ etkilemektedir. Bu nedenle algılanan dışsal prestijin, duygusal emeğin boyutları olan duygusal çaba üzerinde aynı yönde ve anlamlı, duygusal çelişki üzerinde ters yönde ve anlamlı bir etkisinin olduğunu söylemek mümkündür. Buna göre Hipotez1 ve Hipotez2 kabul edilmiştir. Araştırmadan elde edilen sonuçlara göre; konaklama işletmelerinde çalışan işgörenlerin örgüte yönelik dışsal prestij algıları arttıkça, misafirlerle etkileşimleri sırasında sergiledikleri duygusal çaba artmakta ve yaşadıkları duygusal çelişki azalmaktadır.

\subsubsection{Algılanan Dışsal Prestij ve Örgütsel Özdeşleşme Arasındaki iliş̧ki}

Algılanan dışsal prestijin örgütsel özdeşleşmeyle arasındaki ilişkiyi ortaya koymak amacıyla yapılan korelasyon analizi ve yapısal regresyon modeli sonuçları şu şekildedir. Korelasyon bulgularına göre; algılanan dışsal prestij ile örgütsel özdeşleşmenin örgütle özdeşleşme boyutu $(r=0,499 ; p<0,01)$ ve grup içi özdeşleşme boyutu $(r=0,402 ; p<0,01)$ arasında istatistiksel açıdan anlamlı, pozitif ve orta dereceli bir ilişki olduğu görülmektedir. Algılanan dışsal prestijinörgütsel özdeşleşmeyi nasıl etkilediğini ölçmek üzere oluşturulan modelin uyum değerlerinin $\left(\mathrm{x}^{2}=\right.$ $\left.337,064, \mathrm{df}=70, \mathrm{p}=, 000 ; \mathrm{x}^{2} / \mathrm{df}=4,815, \mathrm{GFI}=0,92, \mathrm{CFI}=0,93, \mathrm{RMSEA}=0,080\right)$ kabul edilebilir 
sınırlar içinde olması, modelin yapısal olarak uygun olduğunu göstermektedir. Modele göre, algılanan dışsal prestij, örgütsel özdeşleşmenin boyutlarından örgütle özdeşleşmeyi $(\beta=0,68$; $p<0,01)$ ve grup içi özdeşleşmeyi $(\beta=0,66 ; p<0,01)$ etkilemektedir. Bu nedenle algılanan dışsal prestijin, örgütsel özdeşleşmenin boyutları olan örgütle özdeşleşme ve grup içi özdeşleşme üzerinde aynı yönde ve anlamlı bir etkisinin olduğunu söylemek mümkündür. Buna göre Hipotez 3 ve Hipotez 4 kabul edilmiştir. Araştırmadan elde edilen sonuçlara göre; konaklama işletmelerinde çalışan işgörenlerin örgüte yönelik dışsal prestij algıları arttıkça, gerek örgütün bütünüyle gerekse bağlı oldukları departmanlarla özdeşleşme düzeyleri artmaktadır.

\subsection{3. Örgütsel Özdeşleşme ve Duygusal Emek Arasındaki ilişki}

Örgütsel özdeşleşmenin duygusal emek ile olan ilişkisine yönelik bulgulara göre; örgütle özdeşleşme ile duygusal emeğin duygusal çaba boyutu arasında $(r=0,465 ; p<0,01)$ istatistiksel açıdan anlamlı, pozitif ve orta dereceli bir ilişki ve duygusal çelişki boyutu arasında $(r=-0,240$; $p<0,01$ ) istatistiksel açıdan anlamlı, negatif ve zayıf bir ilişki bulunduğu görülmektedir. Grup içi özdeşleşme ile duygusal çaba arasında $(r=0,464 ; p<0,01)$ istatistiksel açıdan anlamlı, pozitif ve orta dereceli bir ilişki ve duygusal çelişki arasında $(r=-0,238 ; p<0,01)$ istatistiksel açıdan anlamlı, negatif ve zayıf bir ilişki gözlenmiştir. Örgütsel özdeşleşmenin duygusal emek üzerindeki etkisini ölçmek üzere oluşturulan yapısal regresyon modelinin uyum değerlerinin $\left(x^{2}=482,453, \mathrm{df}=\right.$ $\left.178, p=, 000 ; x^{2} / d f=2,710, \mathrm{GFI}=0,91, \mathrm{CFI}=0,94, \mathrm{RMSEA}=0,058\right)$ kabul edilebilir sınırlar içinde olması, modelin yapısal olarak uygun olduğunu göstermektedir. Ancak modelde, bazı yolların anlamlı olmadığı görülmüştür. Dolayısıyla anlam ifade etmeyen yollar teker teker modelden çıkarılarak, her işlemden sonra analiz tekrarlanmış ve regresyon katsayıları ile anlamlılık değerleri tekrar incelenmiştir. Bu aşamaların sonunda ulaşılan modelin uyum değerlerinin $\left(x^{2}=486,036\right.$, $\left.\mathrm{df}=180, \mathrm{p}=, 000 ; \mathrm{x}^{2} / \mathrm{df}=2,700, \mathrm{GFI}=0,91, \mathrm{CFI}=0,94, \mathrm{RMSEA}=0,058\right)$ kabul edilebilir sınırlar içinde olduğu görülmüştür. Modele göre; örgütsel özdeşleşmenin boyutlarından biri olan grup içi özdeşleşme boyutunun, duygusal çabayı $(\beta=0,56 ; p<0,01)$ ve duygusal çelişkiyi $(\beta=-0,36$; $p<0,01)$ etkilediği görülmektedir. Bu nedenle örgütsel özdeşleşmenin yalnızca grup içi özdeşleşme boyutunun, duygusal emeğin boyutları olan duygusal çaba üzerinde aynı yönde ve anlamlı, duygusal çelişki üzerinde ters yönde ve anlamlı bir etkisinin olduğunu söylemek mümkündür. Buna göre Hipotez 5 ve Hipotez6 reddedilirken, Hipotez7 ve Hipotez8 kabul edilmiştir. Araştırmadan elde edilen sonuçlara göre; konaklama işletmelerinde çalışan işgörenlerin bağlı bulundukları departmanla özdeşleşme düzeyleri arttıkça, misafirlerle etkileşimleri sırasında sergiledikleri duygusal çaba artmakta ve yaşadıkları duygusal çelişki azalmaktadır.

\subsubsection{Aracılık Etkisinin Yol Analizi Modeliyle Test Edilmesi}

Çalışmada, algılanan dışsal prestij ve duygusal emeğin boyutları arasındaki ilişkide örgütsel özdeşleşmenin boyutlarının aracılık rolü, Baron ve Kenny'nin (1986) öne sürdüğü yöntemle sağlanmıştır. Yazarların öne sürdüğü yönteme göre; aracılık etkisinden bahsedebilmek için i) bağımsız değişken bağımlı değişkeni etkilemeli, ii) bağımsız değişken aracı değişkeni etkilemeli, iii) aracı değişken bağımlı değişkeni etkilemeli ve iv) aracı değişken modele girdiğinde bağımsız değişkenin bağımlı değişken üzerindeki etkisi düşerken, aracı değişkenin de bağımlı değişken üzerindeki anlamlı etkisi sürmelidir (Meydan ve Şeşen, 2011: 130). Eğer bağımsız değişkenle bağımlı değişken arasında anlamlı olmayan ilişki çıkarsa tam aracılık etkisinden veya daha az anlamlı bir ilişki gerçekleşmiş ise kısmi aracılık etkisinden bahsetmek mümkündür (Gürbüz ve Şahin, 2016: 287). 
Buna göre; algılanan dışsal prestijin, duygusal emeğin boyutları olan duygusal çaba üzerinde aynı yönde ve anlamlı $(\beta=0,51 ; p<0,01)$, duygusal çelişki üzerinde ters yönde ve anlamlı $(\beta=-$ $0,27 ; p<0,01)$, örgütsel özdeşleşmenin boyutları olan örgütle özdeşleşme $(\beta=0,68 ; p<0,01)$ ve grup içi özdeşleşme $(\beta=0,66 ; p<0,01)$ üzerinde ise aynı yönde ve anlamlı bir etkisinin olduğu görülmüştür. Ayrıca örgütsel özdeşleşmenin boyutlarından yalnızca grup içi özdeşleşmenin, duygusal emeğin boyutları olan duygusal çaba üzerinde aynı yönde ve anlamlı $(\beta=0,56 ; p<0,01)$, duygusal çelişki üzerinde ters yönde ve anlamlı $(\beta=-0,36 ; p<0,01)$ bir etkisinin olduğu görülmüştür. Bu sonuçlara göre, örgütsel özdeşleşmenin grup içi özdeşleşme boyutunun, algılanan dışsal prestijin duygusal emeğin boyutları üzerindeki etkisine aracılık edip edemeyeceği araştırılmıştır. Örgütsel özdeşleşmenin örgütle özdeşleşme boyutunun duygusal emeğin boyutlarıyla arasında anlamlı bir ilişkiye rastlanmadığı için aracılık modelinden söz etmek mümkün değildir (Gürbüz ve Şahin, 2016: 287).

Aracılık etkisini ölçmek için oluşturulan modelin uyum değerleri $\left(x^{2}=428,494, \mathrm{df}=160, p=\right.$ , $\left.000 ; \mathrm{x}^{2} / \mathrm{df}=2,678, \mathrm{GFI}=0,92, \mathrm{CFI}=0,95, \mathrm{RMSEA}=0,058\right)$ kabul edilebilir sınırlar içindedir ve modelin yapısal olarak uygun olduğunu göstermektedir. Elde edilen bu bulgulara göre; algılanan dışsal prestij grup içi özdeşleşmeyi aynı yönde ve anlamlı olarak etkilemektedir $(\beta=0,63$; $p<0,01)$. Grup içi özdeşleşme duygusal emeğin boyutları olan duygusal çabayı aynı yönde ve anlamlı olarak $(\beta=0,35 ; p<0,01)$, duygusal çelişkiyi $(\beta=-0,29 ; p<0,01)$ ters yönde ve anlamlı olarak etkilemektedir. Tüm bunların yanı sıra, grup içi özdeşleşmenin modele aracı değişken olarak dâhil edilmesiyle, algılanan dışsal prestijin duygusal emeğin duygusal çaba boyutu üzerindeki etkisi azalmış $(\beta=0,29 ; p<0,01)$, duygusal çelişki boyutu üzerindeki etkisi ise anlamsızlaşmıştır $(\beta=-0,09 ; p>0,05)$. Buna göre; örgütsel özdeşleşmenin grup içi özdeşleşme boyutu, algılanan dışsal prestijin duygusal emeğin duygusal çaba boyutu üzerindeki etkisinde kısmi, duygusal çelişki boyutu üzerinde ise tam aracı değişken rolüne sahiptir.

Bu noktada yapılması gereken son işlem, algılanan dışsal prestijin duygusal çaba üzerindeki etkisinde yaşanan değişimin anlamlı olup olmadığının test edilmesidir. Bu amaçla Sobel testinden yararlanılmıştır (Meydan ve Şeşen, 2011: 133). Buna göre; test istatistiği 3,65 ve anlamlılık değeri $p<0,01$ olarak hesaplanmıştır. Bu nedenle algılanan dışsal prestijin duygusal çaba üzerindeki etkisinde grup içi özdeşleşmenin kısmi aracılık etkisinden bahsetmek mümkündür. Buna göre Hipotez9 ve Hipotez10 reddedilirken, Hipotez11 ve Hipotez12 kabul edilmiştir. Araştırmadan elde edilen sonuçlara göre; konaklama işletmeleri işgörenlerinin departmanlarıyla özdeşleşmeleri, örgüte yönelik algıladıkları dışsal prestijle şekillenmekte, bunun sonucu olarak da dışsal prestij algısı ile yaşadıkları duygusal çelişki arasındaki ilişki grup içi özdeşleşme bağlamında oluşmaktadır. Ayrıca işgörenlerin örgüte yönelik dışsal prestij algıları sergiledikleri duygusal çaba düzeylerini etkilerken, departmanlarıyla özdeşleşmeleri arttıkça dışsal prestij algıları yaşadıkları duygusal çaba üzerinde kısmen etkili olmaktadır.

\section{Sonuç ve Öneriler}

Konaklama işletmeleri açısından işgören-misafir etkileşiminin kalitesi, misafirlerin güdülerini, tutumlarını ve satın alma davranışlarını etkilediği için sürdürülebilir rekabetin en önemli unsurlarından biri olarak görülmektedir. Konaklama işletmelerinde misafir memnuniyetini belirleyen önemli ölçütlerden biri de duygusal emek davranışlarının yoğunluğudur. Dolayısıyla duyguların yönetilmesi ve doğru bir şekilde davranışa dönüştürülmesi açısından örgüt yöneticilerinin işgörenlerin dışsal prestij algısını olumlu şekilde etkileyecek ve örgütsel özdeşleşmelerini arttıracak şekilde hareket etmeleri gerekmektedir. 
Dışsal prestij algısı, işgörenleri harekete geçme konusunda motive etmekte ve bu anlamda olumlu bir prestij oluşturmayı planlayan işgören, bulunduğu çevreyle ilişkileri de dikkate almak ve birtakım unsurları seçmek suretiyle uygun davranışa yönelmektedir (Çakır, 2006: 19; Tyler ve Blader, 2003: 355). Davranış sergileme kurallarına uymanın meşru olarak kendilerinden beklendiğini düşünen ve davranışlarının örgütleri iç̧in faydalı olduğuna inanan işgörenler, istenen duyguları içselleştirmek ve sergilemek için misafirle etkileşimleri sırasında çaba sarf ederek kendilerini samimi davranmaya iteceklerdir (Zerbe, 2002: 191). Araştırmadan elde edilen sonuçlar, yazınla tutarlılık sergilemektedir. Buna göre; algılanan dışsal prestij, duygusal çabayla aynı, duygusal çelişkiyle ters yönde ilişkilidir (Mishra, 2011;Oktuğ, 2013). Bununla birlikte üyeler, örgüt dışında yer alan ve kendisince önem verdiği insanların, örgüt hakkında olumlu düşünceler taşıdığı ve dolayısıyla dışsal prestijin çekici olduğu yorumuna sahipse (Bergami ve Bagozzi, 2000: 562), örgüte hissedilen bağ|ılık kişinin sahip olduğu sosyal kimliğe de olumlu şekilde yansıyacaktır (Dutton vd., 1994: 246). Birey örgüte ilişkin taşıdığı olumlu prestij inancını kendi kimliğiyle bütünleştirdiğinde, örgütsel özdeşleşme ortaya çıkar (Kreiner ve Ashforth, 2004: 2). Dışsal prestij algısının, hem örgüt hem de grup düzeyinde örgütsel özdeşleşme üzerinde olumlu bir etkisi bulunmakta ve bu sonuç yazınla örtüşmektedir (Bartels vd., 2007; Carmeli ve Shteigman, 2010; Carmeli vd., 2011; Lipponen, 2001; Lipponen vd., 2005). Bireyin işine ya da örgüte yönelik özdeşleşmesi ise, işyerinde duygusal emeği nasıl sergilediğini etkiler (Burch vd., 2013; Humphrey vd., 2015; Schaubroeck ve Jones 2000). Yüksek düzeydeki bir örgütsel özdeşleşmeyle birey, örgütsel kurallarla daha fazla özdeşleşecek, zihinsel durumunu ve davranış şeklini aktif olarak düzenleyecek ve örgüt tarafından belirtilen davranış kurallarına uyum sağlamak için duygusal emek sergileyecektir (Zeng vd., 2014: 208-210). Araştırmanın sonuçlarıyla tutarlı olarak yazında yer alan çalışmalarda, özdeşleşme duygusal çaba davranışıyla aynı yönde, duygusal çelişki davranışıyla ters yönde ilişkili bulunmuştur (Brotheridge ve Lee, 2003; Côté, 2005; Mishra ve Bhatnagar, 2010; Ünler Öz, 2007). Araştırma bulgularının yazındaki çalışmaların sonuçlarıyla benzerlik taşıması, araştırmaların hizmet sektörünün eğitim, sağlık ve ağırlama gibi alanlarında yapılmış olması ve dolayısıyla sorunsalları benzer olan bu sektörlerin genellikle aynı düşüncede olmasıyla açıklanabilir.

Yapılan araştırmada, konaklama işletmelerinde algılanan dışsal prestijin duygusal emek üzerindeki etkisinde örgütsel özdeşleşmenin aracılık rolü belirlenmeye çalışılmıştır. Buna göre; algılanan dışsal prestijin, duygusal emeğin boyutları olan duygusal çaba üzerinde aynı yönde ve anlamlı $(\beta=0,51 ; p<0,01)$, duygusal çelişki üzerinde ters yönde ve anlamlı $(\beta=-0,27 ; p<0,01)$, örgütsel özdeşleşmenin boyutları olan örgütle özdeşleşme $(\beta=0,68 ; p<0,01)$ ve grup içi özdeşleşme $(\beta=0,66 ; p<0,01)$ üzerinde ise aynı yönde ve anlamlı bir etkisinin olduğu görülmüştür. Ayrıca örgütsel özdeşleşmenin boyutlarından yalnızca grup içi özdeşleşmenin, duygusal emeğin boyutları olan duygusal çaba üzerinde aynı yönde ve anlamlı $(\beta=0,56 ; p<0,01)$, duygusal çelişki üzerinde ters yönde ve anlamlı $(\beta=-0,36 ; p<0,01)$ bir etkisi olduğu ortaya konmuştur. Buna göre; örgütsel özdeşleşmenin grup içi özdeşleşme boyutu, algılanan dışsal prestijin duygusal emeğin duygusal çaba boyutu üzerindeki etkisinde kısmi, duygusal çelişki boyutu üzerinde ise tam aracı değişken rolüne sahiptir.

Araştırmadan elde edilen aracılık testi sonuçları göstermektedir ki, araştırmaya katılan konaklama işletmeleri işgörenlerinin örgüte yönelik dışsal prestij algıları sergiledikleri duygusal çelişki düzeylerini etkilerken, grup içi özdeşleşme modele dahil edildiğinde, departmanlarıyla özdeşleşmeleri arttıkça dışsal prestij algıları yaşadıkları duygusal çelişki üzerinde etkili olama- 
maktadır. Yani bir anlamda, işgörenlerin departmanlarıyla özdeşleşmeleri, örgüte yönelik algıladıkları dışsal prestijle şekillenmekte, bunun sonucu olarak da dışsal prestij algısı ile yaşadıkları duygusal çelişki arasındaki ilişki grup içi özdeşleşme bağlamında oluşmaktadır. Ulaşılan ikinci bir sonuca göre, işgörenlerin örgüte yönelik dışsal prestij algıları sergiledikleri duygusal çaba düzeylerini etkilerken, grup içi özdeşleşme modele dahil edildiğinde, departmanlarıyla özdeşleşmeleri arttıkça dışsal prestij algıları yaşadıkları duygusal çaba üzerinde kısmen etkili olmaktadır. Buradan hareketle, algılanan dışsal prestij ve duygusal çaba ilişkisinde grup içi özdeşleşme dışında başka değişkenlerin de aracı olabileceği sonucuna ulaşılabilir. İşgörenlerin örgütün dışsal prestijine yönelik olumlu algıları, örgütleriyle özdeşleşmelerine neden olur ve bu da işgörenleri misafirle etkileşimleri sırasında duygusal çaba davranışı sergilemeye yönlendirir. Aksine dışsal prestij algısının zayıf olduğu durumlarda işgörenler, örgütleriyle özdeşleşemeyecekler ve sonuç olarak duygusal çelişki yoluyla duygusal emek sergileyeceklerdir. Araştırmanın bulgularının yazındaki çalışmalarla örtüştüğü görülmektedir (Mishra vd., 2012).

Araştırmanın tüm hipotezlerine yönelik sonuçlar Tablo 2'de özetlenmiştir.

Tablo 2:Araştırmanın Hipotezlerine Yönelik Sonuçlar

\begin{tabular}{|c|c|c|}
\hline & Hipotez & Sonuç \\
\hline Hipotez 1 & $\begin{array}{l}\text { Algılanan dışsal prestij, duygusal emeğin duygusal çaba boyutu üzerinde aynı yönde } \\
\text { ve anlamlı bir etkiye sahiptir. }\end{array}$ & KABUL \\
\hline Hipotez 2 & $\begin{array}{l}\text { Algılanan dışsal prestij, duygusal emeğin duygusal çelişki boyutu üzerinde ters yönde } \\
\text { ve anlamlı bir etkiye sahiptir. }\end{array}$ & KABUL \\
\hline Hipotez 3 & $\begin{array}{l}\text { Algılanan dışsal prestij, örgütsel özdeşleşmenin örgütle özdeşleşme boyutu üzerinde } \\
\text { aynı yönde ve anlamlı bir etkiye sahiptir. }\end{array}$ & KABUL \\
\hline Hipotez 4 & $\begin{array}{l}\text { Algılanan dışsal prestij, örgütsel özdeşleşmenin grup içi özdeşleşme boyutu üzerinde } \\
\text { aynı yönde ve anlamlı bir etkiye sahiptir. }\end{array}$ & KABUL \\
\hline Hipotez 5 & $\begin{array}{l}\text { Örgütsel özdeşleşmenin örgütle özdeşleşme boyutu, duygusal emeğin duygusal çaba } \\
\text { boyutu üzerinde aynı yönde ve anlamlı bir etkiye sahiptir. }\end{array}$ & RED \\
\hline Hipotez 6 & $\begin{array}{l}\text { Örgütsel özdeşleşmenin örgütle özdeşleşme boyutu, duygusal emeğin duygusal çe- } \\
\text { lişki boyutu üzerinde ters yönde ve anlamlı bir etkiye sahiptir. }\end{array}$ & RED \\
\hline Hipotez 7 & $\begin{array}{l}\text { Örgütsel özdeşleşmenin grup içi özdeşleşme boyutu, duygusal emeğin duygusal çaba } \\
\text { boyutu üzerinde aynı yönde ve anlamlı bir etkiye sahiptir. }\end{array}$ & KABUL \\
\hline Hipotez 8 & $\begin{array}{l}\text { Örgütsel özdeşleşmenin grup içi özdeşleşme boyutu, duygusal emeğin duygusal çe- } \\
\text { lişki boyutu üzerinde ters yönde ve anlamlı bir etkiye sahiptir. }\end{array}$ & KABUL \\
\hline Hipotez 9 & $\begin{array}{l}\text { Örgütsel özdeşleşmenin örgütle özdeşleşme boyutu, algılanan dışsal prestij ile duy- } \\
\text { gusal emeğin duygusal çaba boyutu arasındaki ilişkide aracı rolü oynayacaktır. }\end{array}$ & RED \\
\hline Hipotez 10 & $\begin{array}{l}\text { Örgütsel özdeşleşmenin örgütle özdeşleşme boyutu, algılanan dışsal prestij ile duy- } \\
\text { gusal emeğin duygusal çelişki boyutu arasındaki ilişkide aracı rolü oynayacaktır. }\end{array}$ & RED \\
\hline Hipotez 11 & $\begin{array}{l}\text { Örgütsel özdeşleşmenin grup içi özdeşleşme boyutu, algılanan dışsal prestij ile duy- } \\
\text { gusal emeğin duygusal çaba boyutu arasındaki ilişkide aracı rolü oynayacaktır. }\end{array}$ & KABUL \\
\hline Hipotez 12 & $\begin{array}{l}\text { Örgütsel özdeşleşmenin grup içi özdeşleşme boyutu, algılanan dışsal prestij ile duy- } \\
\text { gusal emeğin duygusal çelişki boyutu arasındaki ilişkide aracı rolü oynayacaktır. }\end{array}$ & KABUL \\
\hline
\end{tabular}

Çalışma, özellikle turizm alanında işgörenlerin sıklıkla karşılaştığı duygusal emek konusuna katkı sağlamaya çalışmaktadır. Bu çalışma, değişkenlerin bir model içinde bütünleştirilmesine ve aralarındaki ilişkinin ortaya konmasına imkân tanımıştır. Aynı zamanda kavramların konaklama sektöründe aynı anda araştırıldığı yeni çalışmalardan biri olması bakımından da önemlidir. Bununla birlikte, daha önce yapılan çalışmalardan farklı olarak örgütsel özdeşleşme değişkeni örgütle ve grup içi özdeşleşme bazında ayrı ayrı ölçülmeye çalışılmıştır. Bu nedenle araştırmadan elde edilen tespitlerin gerek uygulamaya dönük olarakyöneticilere ve işgörenlere gerekse yönetim ve turizm yazınına önemli katkılar sağlayacağı düşünülmektedir. 
Çalışmadan elde edilen bulgular ışığında, Nevşehir ilinde yer alan konaklama işletmelerine ve onun nezdinde tüm konaklama işletmelerine yönelik birtakım öneriler sunulabilir:

- Yöneticiler örgütün prestijini arttırmaya yönelik yapacakları çalışmalarla, bunun örgüt çevresinde fark edilmesini sağlamak suretiyle işgörenlerinin dışsal prestij algılarını iyileştirmeye çalışmalı ve özellikle örgütleriyle özdeş işgörenlere sahip olmanın yollarını aramalıdır.

- İşletmenin değerli bulunan özelliklerinin örgütün dışında bulunanlar tarafından saygın ve güvenilir olarak algılanmasını sağlamak, bu noktada da hem finansal hem de sosyal performansı arttırmak gerekmektedir. Özellikle referans grupların düşüncelerine önem verilmeli, ağızdan ağıza iletişim ve işletmenin içsel ve dışsal iletişim çabaları arttırılmalıdır. Kurumsal sosyal sorumluluğa katılım da, örgüt açısından varlıklarının anlamını arayan işgörenlerin, iş-yaşam bütünleşmesi yoluyla daha az çelişki yaşamasına yardımcı olacaktır.

- Örgütleriyle özdeş işgörenlere sahip olma noktasında kullanılabilecek önemli stratejilerden biri otonomidir. Daha fazla otonominin teşvik edildiği bir çalışma ortamı sağlandığında, işgörenlerin hizmetlerini kişiselleştirmeleri mümkün olmaktadır. Bu sayede, işgören yalnızca kendi departmanıyla özdeşleşmenin ötesine geçerek, örgütün bütünüyle özdeşleşecek ve misafirle etkileşiminde daha fazla duygusal çaba davranışı sergileyebilecektir.

- Özellikle duygusal çaba sergilemeye eğilimli işgörenleri işletme bünyesine dâhil etmek, çaba sarf eden mevcut işgörenleri örgüt içinde kalma konusunda teşvik etmek ve diğer işgörenleri de bu süreçte motive etmek işletme yöneticilerinin üzerinde durmaları gereken önemli konulardır. Bu bağlamda işletmeler, işe alım süreçlerinde duygusal çaba sergilemeye eğilimli, dışa dönük, uyumlu, öz disiplin sahibi ve gelişime açık işgörenleri seçmeli, belirli aralıklarda düzenleyecekleri hizmet içi eğitimlerle işgörenlerini güçlendirmeli ve örgütte kalmalarını sağlamalıdırlar. Bu sayede örgütte işgörenlerin yaşadığı duygusal çelişki azaltılıp, duygusal çaba arttırılmak suretiyle duygusal emek bir örgüt kültürü haline getirilebilir.

- Konaklama işletmeleri, gerek iç müşterilerinin gerekse dış müşterilerinin taşıdığı profili, duygu, düşünce ve beklentilerinin neler olduğunu saptamak ve özellikle memnuniyeti ölçen araştırmalar yapmak durumundadır. Elde edilecek sonuçlar doğrultusunda, örgütler misyon ve vizyonlarını belirleyerek mevcut hizmet politikalarını geliştirmelidir.

- Misafirleri ile doğru ve verimli bir ilişki kurmak isteyen işletmelerin, işgörenlerin duygusal emeğe ilişkin bakış açılarını değerlendirmeleri önemlidir. Bu nedenle örgüt içerisinde işgörenlerin sorunlarının dinlenmesi ve karşılıklı iletişim ortamı kurulabilmesi için rutin toplantılar düzenlenebilir.

- Duygusal emek, özellikle marka değeri oluşturmada üzerinde durulması gereken önemli konulardan biridir. Çünkü misafirlerin hizmet alımı esnasında işgören ile aralarında gerçekleşebilecek olumsuz bir deneyim, önceki iyi duyguları da etkisizleştirerek olumsuz sonuçlar açığa çıkarabilecektir. Hizmet bir zincir olarak düşünüldüğünde, zincirin halkalarının birinde meydana gelebilecek bir aksaklık tüm deneyimi olumsuz yönde etkileyebilecektir. Bu bakımdan özellikle ön planda yer alan önbüro ve yiyecek-içecek gibi departmanlarda çalışan işgörenlerin sergiledikleri duygusal emeğin, doğru bir şekilde yansıtılması konusunda, yöneticilerin daha belirgin davranış kuralları ortaya koymaları gerekmektedir.

- Araştırmadan elde edilen demografik bulgular göstermektedir ki; araştırmaya katılan örneklemde yer alan işgücü genç ve dinamik bir yapıdadır. Oysaki yaş arttıkça duyguları 
yönetebilme becerisinde de artış meydana gelmekte ve duygusal çelişki davranışı sergileme olasılıkları da azalmaktadır (Özdemir vd., 2013: 307-318). Çalışan işgörenlerin büyük çoğunluğu erkektir. Pozitif duyguların gösterilmesini gerektiren hizmet işlerinde kadınların doğaları gereği duygularını kontrol etmede, empati kurmada ve duygusal tepkiler vermede erkeklere nazaran daha başarılı oldukları bilinmektedir (Hocshild, 1983: 164). Bu durumda, özellikle ön planda yer alan pozisyonlara işe alımlarda bu kritere önem verilmesi gerekebilir. Sonuçlar sektörün kanayan bir yarasını da ortaya koymaktadır. Turizm eğitimi almış üniversite mezunu (sektördeki adıyla mektepli) işgörenlerden ziyade, alaylı olarak tabir edilen ve çıraklık, kalfalık, ustalık zinciri içinde yetişmiş kesimin çoğunlukta olduğu görülmektedir. Bu durum, mekteplileri sektörde görev almaktan ya da kalıcı olmaktan uzaklaştıran bir unsurdur. Son zamanlarda buna yönelik alınan tedbirlerden biri meslek yasası çalışmalarının yürütülmesi olmuştur. Bu sayede istihdam zorlukları nedeniyle turizm sektörünü terk etmek zorunda kalan eğitimli personelin sektöre geri kazandırılması mümkün olabilecektir. Bu da hizmet kalitesini ve prestiji olumlu yönde etkileyecektir. Son olarak, sektörde ve otelde çalışma sürelerinin kısa olması da özellikle örgütle özdeşleşmeyi olumsuz yönde etkileyen bir durumdur. Nitekim araştırma sonuçlarına da örgütle özdeşleşmenin duygusal çaba üzerinde etkisi bulunmadığı şeklinde yansımıştır. İşgörenlerin örgütle özdeşleşmesini hedefleyen örgütler, örgütün algılanan değerini ve mevcut uygulamalarını diğer örgütlerle karşılaştırmak, örgütün algılanan prestijini arttırmak, işgörenin örgütteki çalışma sürecini yönetmek ve insan kaynakları uygulamalarını iyileştirmek durumundadır. Bu süreçte özellikle liderlere büyük görev düşmektedir. Aynı zamanda bir rol model olan liderin yönlendirme şekli, işgören için bir esin kaynağı olacak ve bu yönlendirmeden çıkardığı anlam, işgörenin örgütle özdeşleşmesinde önemli bir rol oynayacaktır.

- Son zamanlarda ülke genelinde yaşanan ekonomik istikrarsızlık, Kapadokya bölgesinin tüm sezona yayılan turizm anlayışını da olumsuz yönde etkilemiştir. İşten çıkarılmaların ve ücretsiz izinlerin artması istihdam konusunda yaşanan sıkıntıları göz önüne sererken, zaman zaman artan talebe niteliksiz işgörenlerle cevap verilmeye çalışılması da hizmet kalitesinin düşmesine neden olmuştur. Bu durum, işletmelere yönelik prestij algısını kötü yönde etkilemekte ve işgörenler bundan olumsuz şekilde etkilenmektedir. İlaveten, işgücü devir hızının yüksek olması da işgörenlerin örgütleriyle özdeşleşmelerini engellemekte ve işgörenler davranış kurallarıyla bütünleşmek konusunda çelişki yaşamaktadırlar. Genelden özele uzanan bu tür sıkıntıların önüne geçebilmek adına, alınabilecek en iyi tedbirlerden biri bölgede yaşanacak bir kümelenme hareketi olabilir. Turizm sektörünün benzer ya da birbirini tamamlayan iş kollarında faaliyet gösteren işletmelerinin, kamu kurumları, sanayi ve ticaret odaları, sivil toplum kuruluşları gibi destek kurumlarının, üniversite, meslek okulları, araştırma ve geliştirme merkezleri gibi eğitim ve araştırma kurumlarının bir araya gelerek ekonomide yaşanan istikrarsızlığı azaltmaya yönelik bütünleşik çaba sergilemesi birlikten kuvvet doğurabilecektir. Bu sayede, yalnızca rekabetçi değil aynı zamanda çevreye ve topluma duyarlı bir sanayi yapısıyla birlikte sürdürülebilir turizme hizmet edilebilecek, katma değer oluşturacak değişim ve yenilikler gerçekleştirilecek ve turizm sektörünün dinamizmine uygun nitelikli işgücü yetiştirilebilecektir.

Hızla değişen piyasa koşullarında konaklama işletmelerinin duygusal emek konusuna her geçen gün daha fazla önem vermeleri gereğinden hareketle, öncü olabileceği düşünülen geniş perspektifli bu çalışma bir başlangıç olarak kabul edilmelidir. Bundan sonra kapsamı daraltılmış, 
derinliği arttırılmış çalışmalar ile konu hakkında daha özgün sonuçlar elde edilebilir. Araştırmanın gerçekleştirildiği örneklem, Nevşehir ilinde yer alan konaklama işletmeleri işgörenlerinden oluşmaktadır. Araştırmanın yürütüldüğü örneklemde çalışan işgörenlerin duygusal emek sergilemelerini etkileyecek şekilde örgütlerine yönelik dışsal prestij algılarının ve örgütsel özdeşleşme düzeylerinin yüksek olduğunu söylemek mümkündür. Ancak gelecekte yapılacak olan çaıı̧̧malarda farklı örneklemlerde ele alındığında ve örgütün iç ve dış dinamikleri de analize dâhil edildiğinde, değişkenler arasındaki ilişkilerin farklılık göstereceği söylenebilir. Bu kapsamda farklı alanlarda yapılacak çalışmalardan elde edilen bulgular karşılaştırılabilir. Ayrıca araştırmada kullanılan verilerin anket yöntemi ile sağlanmış olması da kısıtıılıklardan biridir. Sonraki araştırmalarda görüşme yöntemi yoluyla veri elde edilmesi çalışmaların güvenilirliği açısından da katkı sağlayıcı bir faktör olacaktır. Bununla birlikte, ele alınan değişkenler arasındaki ilişkide demografik değişkenlerin aracılık veya düzenleyicilik rollerini inceleyen araştırmaların yazına katkı sağlayabileceği değerlendirilmelidir. Ayrıca, bu alanda yapılacak nicel ve nitel ilave çalışmalara ihtiyaç duyulduğu düşünülmektedir. 


\section{Kaynaklar}

Akyüz, Meral.; Dalkılıç Yılmaz, Filiz (2015). Konaklama İşletmelerinde Örgütsel Özdeşleşme ve Örgütsel İletişimin İşgörenlerin İşten Ayrılma Niyetine Etkisi. Kastamonu Üniversitesi İktisadi ve Idari Bilimler Fakültesi Dergisi, Vol. 8, No. 2: 138-143.

Albert, Stuart; Ashforth, Blake E.; Dutton, Jane E. (2000), “Organizational Identity and Identification: Charting New Waters and Building New Bridges", Academy of Management Review, Vol. 25, No: 13-17.

Ashforth, Blake E.; Humphrey, Ronald H. (1993), "Emotional Labor in Service Roles: The Influence of Identity",Academy of Management Review, Vol. 18, No. 1: 88-115.

Ashforth, Blake E.; Mael, Fred (1989), "Social Identity Theory and the Organization", Academy of Management Review, Vol. 14, No. 1: 20-39.

Ashforth, Blake; Tomiuk, Marc A. (2000), "Emotional Labor and Authenticity: Views from Service Agents”, Emotion in Organizations, Sage Publications, ABD:184-204.

Bamber, E. Michael; Iyer, Venkataraman M. (2002), “Big 5 Auditors' Professional and Organizational Identification: Consistency or Conflict?", Auditing: A Journal of Practice \& Theory, Vol. 21, No. 2: 21-38.

Baron, Reuben M.;Kenny, David A. (1986), “The Moderator-Mediator Variable Distinction in Social Psychological Research: Conceptual, Strategic, and Statistical Considerations",Journal of Personality and Social Psychology, Vol. 51, No. 6: 1173-82.

Bartels, Jos; Pruyn, Ad; Jong, Menno (2009), “Employee Identification Before and After an Internal Merger: A Longitudinal Analysis", Journal of Occupational and Organizational Psychology, Vol. 82, No. 1: 113-128.

Bartels, Jos; Pruyn, Ad; Jong, Menno De; Joustra, Inge (2007), "Multiple Organizational Identification Levels and the Impact of Perceived External Prestige and Communication Climate", Journal of Organizational Behavior, Vol. 28, No. 2: 173-190.

Bergami, Massimo; Bagozzi, Richard P. (2000), "Self-Categorization, Affective Commitment and Group Self-Esteem as Distinct Aspects of Social Identity in the Organization", British Journal of Social Psychology, Vol. 39, No. 4: 555-577.

Bhattacharya, Chitra Bhanu.; Elsbach, Kimberly D. (2002), “Us versus Them: The Roles of Organizational Identification and Disidentification in Social Marketing Initiatives", Joaurnal of Public Policy \& Marketing, Vol. 21, No. 1: 26-36.

Bhattacharya, Chitra B.; Rao, Hayagreeva; Glynn, Mary Ann (1995), “Understanding the Bond of Identification: An Investigation of Its Correlates among Art Museum Members", The Journal of Marketing, Vol. 59, No. 4: 46-57.

Brotheridge, Ce'Leste M.; Lee, Raymond T. (2003), "Development and validation of the Emotional Labour Scale", Journal of Occupational and Organizational Psychology, Vol. 76: 365-379.

Bullis, Connie A.; Tompkins, Phillip K. (1989), "The Forest Ranger Revisited: A Study of Control Practices and Identification", Communications Monographs, Vol. 56, No. 4: 287-306.

Burch, Gerald F.; Batchelor, John H.; Humphrey, Ronald H. (2013), "Emotional Labor for Entrepreneurs: A Natural and Necessary Extension", Entrepreneurship Research Journal, Vol. 3, No. 3: 331-366.

Büyüköztürk, Şener (2005), “Anket Geliştirme”, Türk Eğitim Bilimleri Dergisi, C. 3, S. 2: 133-151.

Carmeli, Abraham (2005), "Perceived External Prestige, Affective Commitment, and Citizenship Behaviors". Organization Studies, Vol. 26, No. 3: 443-464.

Carmeli, Abraham; Atwater, Leanne; Levi, Avi (2011), “How Leadership Enhances Employees' Knowledge Sharing: The Intervening Roles of Relational and Organizational Identification", The Journal of Technology Transfer, Vol. 36, No. 3: 257-274.

Carmeli, Abraham; Freund, Anat (2002), "The Relationship between Work and Workplace Attitudes and Perceived External Prestige", Corporate Reputation Review, Vol. 5, No. 1: 51-68.

Carmeli, Abraham; Shteigman, Anat (2010), "Top Management Team Behavioral Integration in Small-Sized Firms: A Social Identity Perspective", Group Dynamics: Theory, Research, and Practice, Vol. 14, No. 4: 318-331.

Chu, Kay Hei-Lin; Murrmann, Suzanne K. (2006), "Development and Validation of the Hospitality Emotional Labor Scale", Tourism Management, Vol. 27, No. 6: 1181-1191.

Cialdini, Robert B.; Thorne, Avril; Borden, Richard J.; Walker, Marcus Randall; Freeman, Stephen; Sloan, Lloyd Reynolds (1976), "Basking in Reflected Glory: Three (Football) Field Studies", Journal of Personality and Social Psychology, Vol. 34, No. 3: 366-375. 


\section{Eskişehir Osmangazi Üniversitesi iiBF Dergisi}

Coté, Stéphane (2005), “A Social Interaction Model of the Effects of Emotion Regulation on Work Strain”, Academy of Management Review, Vol. 30, No. 3: 509-530.

Çakır, Esra (2006). Anadolu Öğretmen Liselerinde Okuyan Öğrencilerin Depresyon ve Motivasyon Düzeyleri. Yayımlanmamış Yüksek Lisans Tezi. Sakarya Üniversitesi, Sosyal Bilimler Enstitüsü, Sakarya.

Diefendorff, James M.; Gosserand, Robin H. (2003), “Understanding The Emotional Labor Process: A Control Theory Perspective", Journal of Organizational Behavior, Vol. 24, No. 8: 945-959.

Dutton, Jane E.; Dukerich, Janet M. (1991), "Keeping an Eye on the Mirror: The Role of Image and Identity in Organizational Adaptation", Academy of Management Journal, Vol. 34: 517-554.

Dutton, Jane E.; Dukerich, Janet M.; Harquail, Celia V. (1994), “Organizational Images and Member Identification”, Administrative Science Quarterly, Vol. 39, No. 2: 239-263.

Edwards, Martin R. (2005), “Organizational Identification: A Conceptual and Operational Review”, International Journal of Management Reviews, Vol. 7, No. 4: 207-230.

Ekman, Paul (1973), “Darwin and Facial Expression: A Century of Research in Review”, Academic Press, New York: 251255.

Epitropaki, Olga (2013), “A Multi-Level Investigation of Psychological Contract Breach and Organizational Identification through the Lens of Perceived Organizational Membership: Testing a Moderated-Mediated Model", Journal of Organizational Behavior, Vol. 34, No. 1: 65-86.

Fisher, Robert; Wakefield, Kirk (1998), "Factors Leading to Group Identification: a Field Study of Winners and Losers", Psychology \& Marketing, Vol. 15, No. 1: 23-40.

Fuller, J. Bryan; Hester, Kim; Barnett, Tim; Relyea, Clint; Frey, Len (2006), "Perceived Organizational Support and Perceived External Prestige: Predicting Organizational Attachment for University Faculty, Staff, and Administrators", The Journal of Social Psychology, Vol. 146, No. 3: 327-347.

Fuller, J. Bryan; Marler, Laura; Hester, Kim; Frey, Len; Relyea, Clint (2006), “Construed External Image and Organizational Identification: A Test of the Moderating Influence of Need for Self-Esteem",The Journal of Social Psychology, Vol. 146, No. 6: 701-716.

Fuller, Jerry Bryan; Hester, Kim; Barnett, Tim; Relyea, Clint; Frey, Len; Beu, Danielle (2006), "Perceived External Prestige and Internal Respect: New Insights into the Organizational Identification Process", Human Relations, Vol. 59, No. 6: 815-846.

Fulmer, Ingrid Smithey; Barry, Bruce (2009), "Managed Hearts and Wallets: Ethical Issues in Emotional Influence by and Within Organizations", Business Ethics Quarterly, Vol. 19, No. 2: 155-191.

Grandey, Alicia A. (2003), "When "The Show Must Go On: Surface Acting And Deep Acting As Determinants Of Emotional Exhaustion And Peer-Rated Service Delivery", Academy of management Journal, Vol. 46, No, 1: 86-96.

Gürbüz, Sait; Şahin, Faruk (2016). Sosyal Bilimlerde Araştırma Yöntemleri Felsefe-Yöntem-Analiz (3. bs.). Ankara: Seçkin Yayıncılık: 287-288.

Hair, Joseph F.; Black, William Cormack; Babin, Barry J; Anderson, Rolph; Tatham, Ronald L. (1998), “Multivariate Data Analysis". Upper Saddle River, NJ: Prentice Hall: 289.

Herrbach, Olivier; Mignonac, Karim; Gatignon, Anne-Laure (2004), "Exploring the Role of Perceived External Prestige in Managers' Turnover Intentions”, The International Journal of Human Resource Management, Vol. 15, No. 8: 13901407.

Hochschild, Arlie Russell (1983/2003). "The Managed Heart: Commercialism of Human Feeling”, Berkeley, University of California Press: 7-155.

Hochschild, Arlie Russell (1990), "Ideology and Emotion Management: A Perspective and Path for Future Research", Albany, State University of New York Press: 117-142.

Homans, George C (1961), “Social Behavior: Its Elementary Forms”, New York: Harcourt, Brace, \& World: 354.

Huynh, Truc; Alderson, Marie; Thompson, Mary (2008), "Emotional Labour Underlying Caring: An Evolutionary Concept Analysis", Journal of Advanced Nursing, Vol. 64, No. 2: 195-208.

Iyer, Venkataraman M.; Bamber, E. Michael; Barefield, Russell M. (1997), “Identification of Accounting Firm Alumni with their Former Firm: Antecedents and Outcomes", Accounting, Organizations and Society, Vol. 22, No. 3: 315336.

İşcan, Ömer Faruk (2006), “Dönüştürücü/Etkileşimci Liderlik Algısı ve Örgütsel Özdeşleşme Ilişkisinde Bireysel Farklılıkların Rolü", Akdeniz iiBF Dergisi, C. 11, S. 6: 160-177. 
Jetten, Jolanda; Schmitt, Michael T.; Branscombe, Nyla R.; Mckimmie, Blake M. (2005), "Suppressing the Negative Effect of Devaluation on Group Identification: The Role of Intergroup Differentiation and Intragroup Respect", Journal of Experimental Social Psychology, Vol. 41, No. 2: 208-215.

Karabey, Canan Nur; İ̧̧can, Ömer Faruk; “Örgütsel Özdeşleşme, Örgütsel İmaj ve Örgütsel Vatandaşlık Davranışı Illişkisi: Bir Uygulama”, Atatürk Üniversitesi Iktisadi ve Idari Bilimler Dergisi, C. 21, S. 2: 231-241.

Kim, Hae-Ryong; Lee, Moonkyu; Lee, Hyoung-Tark; Kim, Na-Min (2010), "Corporate Social Responsibility and Employee-Company Identification", Journal of Business Ethics, Vol. 95, No. 4: 557-569.

Kim, Min Joo.; Han, Han, Suk Young (2009), “Relationship between Emotional Labor Consequences and Employees' Coping Strategy",Asia Pacific Journal of Tourism Research, Vol. 14, No. 3: 225-239.

Knippenberg, Daan; Schie, Els (2000), "Foci and Correlates of Organizational Identification", Journal of Occupational and Organizational Psychology, Vol. 73, No. 2: 137-147.

Kreiner, Glen E.; Ashforth, Blake E. (2004), "Evidence toward an Expanded Model of Organizational Identification", Journal of Organizational Behavior, Vol. 25, No. 1: 1-27.

Lee, Sang M. (1971), "An Empirical Analysis of Organizational Identification”, Academy of Management Journal, Vol. 14, No. 2: 213-226.

Lipponen, Jukka; Helkama, Klaus; Olkkonen, Maria E.; Juslin, Milla (2005), “Predicting the Different Profiles of Organizational Identification: A Case of Shipyard Subcontractors", Journal of Occupational and Organizational Psychology, Vol. 78, No. 1: 97-112.

Liu, Yan; Lam, Long Wai; Loi, Raymond (2014), “Examining Professionals' Identification in the Workplace: The Roles of Organizational Prestige, Work-Unit Prestige, and Professional Status", Asia Pacific Journal of Management, Vol. 31, No. 3: 789-810.

Mael, Fred A.; Ashforth, Blake E. (1992), “Alumni and Their Alma Mater: A Partial Test of the Reformulated Model of Organizational Identification", Journal of Organizational Behavior, Vol. 13, No. 2: 103-123.

March, James G.; Simon, Herbert Alexander (1958), Organisations, Newyork: Wiley: 75-76.

Meydan, Cem Harun; Şeşen, Harun (2011), “Yapısal Eşitlik Modellemesi AMOS Uygulamaları”,Ankara: Detay Yayıncılık: 130-133.

Middleton, Dewight R. (1989), “Emotional style: The cultural ordering of emotions”, Ethos, Vol. 17, No. 2: 187-201.

Mishra, Sushanta Kumar (2011), "Sales Employee's Emotional Labor: A Question of Image or Support, in What Have We Learned”, Emerald Group Publishing Limited: 107-131.

Mishra, Sushanta Kumar (2013), "Perceived External Prestige and Employee Outcomes: Mediation Effect of Organizational Identification", Corporate Reputation Review, Vol. 16, No. 3: 220-233.

Mishra, Sushanta Kumar (2014), “Linking Perceived Organizational Support to Emotional Labor”, Personnel Review, Vol. 43, No. 6: 845-860.

Mishra, Sushanta Kumar; Bhatnagar, Deepti (2010), “Linking Emotional Dissonance and Organizational Identification to Turnover Intention and Emotional Well-Being: A Study of Medical Representatives in India", Human Resource Management, Vol. 49, No. 3: 401-419.

Mishra, Sushanta Kumar; Bhatnagar, Deepti; D’cruz, Premilla; Noronha, Ernesto (2012), “Linkage between Perceived External Prestige and Emotional Labor: Mediation Effect of Organizational Identification among Pharmaceutical Representatives in India", Journal of World Business, Vol. 47: 204-212.

Morris, J. Andrew; Feldman, Daniel C. (1996), "The Dimensions, Antecedents, and Consequences of Emotional Labor", The Academy of Management Review, Vol. 21, No. 4: 986-1010.

Oktuğ, Zeynep (2013), “Algılanan Örgütsel Destek İle Duygusal Emek Davranışları Arasındaki İlişkide Algılanan Örgütsel Prestijin Biçimlendirici Etkisi”, Elektronik Sosyal Bilimler Dergisi, C. 12: 370-381.

Öcel, Hatem (2013), “Örgüt Kimliğinin Gücü, Algılanan Örgütsel Prestij ve Kişi-Örgüt Uyumu ile Bağlamsal Performans Arasındaki İlişkiler: Örgütsel Bağlıı̆̆ın Aracı Rolü”, Türk Psikoloji Dergisi, Vol. 28, No. 71: 37-53.

Özdemir, Gaye; Yalçın, Mustafa; Akbıyık, Melis (2013), "Hizmet Sektöründe Duygusal Emek Davranışlarının Müşteri İlişkileri Üzerindeki Etkisi: Boyner Örneği”, e-Journal of New World Sciences Academy, Vol. 8, No. 3: 301-320.

Podnar, Klement (2011), "Perceived External Prestige, Organizational Identification and Organizational Commitment: An Empirical Examination”, Teorija in Praksa Let, Vol. 48, No. 6: 1611-1627. 


\section{Eskişehir Osmangazi Üniversitesi iiBF Dergisi}

Reade, Carol (2001), "Antecedents of Organizational Identification in Multinational Corporations: Fostering Psychological Attachment to the Local Subsidiary and the Global Organization", International Journal of Human Resource Management, Vol. 12, No. 8: 1269-1291.

Riketta, Michael (2005), “Organizational Identification: A Meta-Analysis", Journal of Vocational Behavior, Vol. 66, No. 2: 358-384.

Schaubroeck, John; Jones, James R. (2000), "Antecedents of Workplace Emotional Labor Dimensions and Moderators of Their Effects on Physical Symptoms." Journal of Organizational Behavior, Vol. 21, No. 2: 163-183.

Scott, Susanne. G., \& Lane, Vicki R. (2000). A stakeholder approach to organizational identity. Academy of Management review, Vol. 25, No. 1: 43-62.

Seçer, Şebnem; Tınar, Mustafa Yaşar (2004), “iş̧ Yerinde Tükenmişlik Kaynağı Olarak Duygusal Emek: Hemşireler Üzerinde Yapılan Bir Araştırma”, 9. Ulusal Ergonomi Kongresi, 16-18 Ekim 2003: 814-830.

Sezgin Nartgün, Şenay; Kalay, Mustafa (2014), "Öğretmenlerin Örgütsel Destek, Örgütsel Özdeşleşme ile Örgütsel Sinizm Düzeylerine İlişkin Görüşleri”, Turkish Studies - International Periodical For The Languages, Literature and History of Turkish or Turkic, C. 9, S. 2: 1361-1376.

Shamir, Boas (1991), “Meaning, Self and Motivation in Organizations”, Organization Studies, Vol. 12, No. 3: 405-424.

Smidts, Ale; Pruyn, Ad Th H.; Van Riel, Cees Bm. (2001), "The Impact of Employee Communication and Perceived External Prestige on Organizational Identification," Academy of Management Journal, Vol. 44, No. 5: 1051-1062.

Turner, John C.,; Tajfel, Henri(1986), "The Social Identity Theory of Intergroup Behavior", Psychology of Intergroup Relations, (Ed. Stephen Worchel and William G. Austin), Chicago: Nelson-Hall: 7-24.

Tak, Bilçin; Çiftçioğlu, Aydem (2009), “Algılanan Örgütsel Prestij lle Örgütsel Bağlılık ve Örgütsel Özdeşleşme Arasındaki İlişkilerin İncelenmesine Yönelik Bir Araştırma”, Akdeniz Üniversitesi IiBF Dergisi, C. 18: 100-116.

Turunç, Ömer; Çelik, Mazlum (2010), “Örgütsel Özdeşleşme ve Kontrol Algılamalarının, Çalışanların İşten Ayrılma Niyeti ve İş Performansına Etkileri”, Atatürk Üniversitesi Iktisadi ve Idari Bilimler Dergisi, C. 24, S. 3: 163-181.

Tyler, Tom R.; Blader, Steven L. (2003), "The Group Engagement Model: Procedural Justice, Social Identity, and Cooperative Behavior", Personality and Social Psychology Review, Vol. 7, No. 4: 349-361.

Ünler Öz, Ela (2007), “Duygusal Emek Davranışlarının Çalışanların İş Sonuçlarına Etkisi”, İstanbul: Beta Yayınları: 90.

Van Dijk, Pieter A.; Brown, Andrea Kirk (2006), “Emotional Labour and Negative Job Outcomes: An Evaluation of the Mediating Role of Emotional Dissonance", Journal of Management \& Organization, Vol. 12, No. 2: 101-115.

Wan-Huggins, Veronica N.; Riordan, Christine M.; Griffeth, Rodger W. (1998), "The Development and Longitudinal Test of a Model of Organizational Identification", Journal of Applied Social Psychology, Vol. 28, No. 8: 724-749.

Xiuli, Tang; Yingkang, Gu (2016), "Forced Smiles or True Feelings: Impact of Organizational Identification and Organization-Based Self-Esteem on Service Employees' Emotional Labor", Tourism Tribune, Vol. 31, No. 1: 68-80.

Yeşiltaş, Murat; Türkmen, Fatih; Ayaz, Nurettin (2011), "Otel İşletmelerinde Algılanan Örgütsel Prestijin Örgütsel Vatandaşlık Davranışları Üzerindeki Etkileri”, C.Ü. Iktisadi ve Idari Bilimler Dergisi, C. 12, S. 2: 171-189.

Zeng, Yan; Chen, Xi; Chen, Yiwen (2014), “Impact of Emotional Intelligence on Emotional Labor Strategy: the Mediating Effects of General Self-Efficacy and Organizational Identification", In: International Conference on Computer Science and Service Systems, June 13th-15th, 2014: 207-210.

Zengin, Eyüp; Erdal, Ayhan (2000), “Hizmet Sektöründe Toplam Kalite Yönetimi”,Journal of Qafqaz University, Vol. 3, No. 1: 43-56.

Zerbe, Wilfred J. (2002), "Emotional Dissonance and Employee Well-Being”, Managing Emotions in the Workplace,(Ed. N. M. Ashkanasy, W. J. Zerbe, C. E. J. Hartel), London: M. E. Sharpe: 189-214. 


\section{Extended Summary}

\section{The Mediating Role of Organizational Identification on the Effects of Perceived External Prestige on Emotional La- bor: A Research in Lodging Companies}

This study aims to reveal the mediating role of organizational identification on the effects of external prestige of employees in lodging companies on their emotional labor. Perceived external prestige is; "what a member believes outsiders think about their organization" (Dutton and Dukerich, 1991: 518). Emotional labor has started to gain importance in the organizational behavior literature, and there are definitions of emotional labor such as; "the job of showing the effort to feel the exactemotions required by the business" (Hochschild, 1990: 118); "the act of displaying appropriate emotion" (Ashforth and Humphrey, 1993: 90)"; "the effort, planning, and control needed to express organizationally desired emotion during interpersonal transaction" (Morris and Feldman, 1996: 987-989). Organizational identification is defined as "a perceived oneness with an organization and theexperience of the organization's successes and failures as one's own" (Mael and Ashforth, 1992: 123) and "to the extent that the group category is psychologicallyaccepted as part of the self, an individualis said to be identified with the group." (Scott and Lane 2000: 46). Employees' positive perceptions of the organization's external prestige cause them to identify with their organizations, and this leads employees to exhibit emotional effort during their interaction with the guest. The negative perception of external prestige will reduce the identification of individuals with the organization. When employees do not identify themselves with their organizations, they think that the value of being a member of the group is low, and they tend to show little compliance with group norms (Homans, 1961: 354) and do not act for the benefit of the organization (Bhattacharya and Elsbach, 2002: 27). Therefore, when perceived external prestige is perceived as low by the employees, they will exhibit emotional labor through emotional contradiction (Mishra, 2011: 123).

It is determined that the population of the study as the employees working in four and five-star hotels that have "Tourism Operation Certificate" from the Ministry of Culture and Tourism. In this study, the purposive sampling method, which is one of the non-random sampling methods, was used to collect the required data. The sample size that could represent the population has been determined as 340 employees, considering a $95 \%$ confidence interval and a $5 \%$ error margin, considering the capacities of hotel establishments. The data were collected through aquestionnaire. The reliability and validity of all three scales used in this study have already been tested in Turkish literature. The scales developed by Mael and Ashforth (1992) were used to measure employees' perceptions of external prestige and levels of organizational identification. The emotional labor scale developed by Chu and Murrmann (2006) was used to measure the emotional labor exhibited by employees. SPSS 24.0 and AMOS 24.0 statistical programs were used to analyze the data and the structural equation model was tested. Chi-square (X2), Degree of Freedom (df) and Chisquare/df ratios, Goodness-of-Fit Index (GFI), Comparative Fit Index (CFI), and Root Mean Square Error of Approximation (RMSEA) were evaluated to assess the suitability of the proposed model. Kaiser-Meyer-Olkin (KMO) test was used to check the adequacy of the sample size for Confirmatory Factor Analysis (CFA). KMO value of 0.90 indicated that the sample size was adequate. By using AMOS 24.0 statistical program, the scales were tested. As a result of the analysis, the one-factor structure of perceived external prestige scale, and the first-level two-factor structure of organizational identification and emotional labor scales are confirmed.

Correlation analysis and structural regression models were used to test the research hypotheses developed in line with the theoretical framework of the study. According to this; perceived external prestige has a positive and significant effect on the emotional effort $(\beta=0.51 ; p<0.01)$ and a negative and significant effect on emotional contradiction $(\beta=$ $-0.27 ; p<0.01$ ), which are both the dimensions of emotional labor. Also perceived external prestige hasa positive and significant effect on identification with organization $(\beta=0.68 ; p<0.01)$ and intra-group identification $(\beta=0.66 ; p<0.01)$, which are the dimensions of organizational identification. In addition, among the dimensions of organizational identification, only intra-group identification has positive and significant effect $(\beta=0.56 ; p<0.01)$ on the emotional effort, and a negative and significant effect on emotional contradiction $(\beta=-0,36 ; p<0,01)$. According to this; the intra-group identification dimension of organizational identification has a partial mediating variable role on the effect of perceived external prestige on the emotional effort dimension of emotional labor, and a full mediating variable role of perceived external prestige on the emotional contradiction dimension of emotional labor. The mediation test results show that while the accommodation companies participating in the research affect the level of emotional contradiction that their employees exhibit external prestige perceptions, when the intra-group identification is included in the model, the perceptions of external prestige do not affect the emotional contradiction they experience with their departments. The results of the mediation test obtained from the research shows that the perception of the external prestige of the employees of the lodging companies participating in the research affects the level of emotional contradiction they exhibit. However, when intra-group identification is included in the model, as employees' identification with their 


\section{Eskişehir Osmangazi Üniversitesi ïiBF Dergisi}

department increases, their perceptions of external prestige cannot influence the emotional contradiction they experience. In other words, the identification of employees with their departments is shaped by the external prestige they perceive towards the organization, and as a result, the relationship between the perception of external prestige and their emotional contradiction occurs within the context of intra-group identification. According to a second conclusion, while employees' perceptions of external prestige towards the organization affect their level of emotional effort, when intra-group identification is included in the model, their perceptions of external prestige are partially influenced by the emotional effort they experience with their departments. Hence, it can be concluded that other variables than intragroup identification may also be mediators in the relationship between perceived external prestige and emotional effort. Employees' positive perceptions of the organization's external prestige cause them to identify with their organizations, which in turn directs employees to exhibit emotional effort during their interaction with the guest. On the contrary, in cases where the external perception of prestige is weak, employees will not be able to identify with their organization and consequently exhibit emotional labor through emotional contradiction. It is seen that the research findings coincide with the studies in the literature (Mishra et all., 2012).

The study tries to contribute to emotional labor, which is frequently encountered by employees, especially in the field of tourism. This study provided the integration of variables into a model and revealed the relationship between them. This study is also important in that it is one of the new studies in which these concepts are investigated simultaneously in the hospitality industry. However, unlike previous studies, organizational identification variable was tried to be measured separately based on identification with the organization and within the group. For this reason, it is thought that the findings obtained from the research will make significant contributions to both managers and employees as well as to management and tourism literature. 